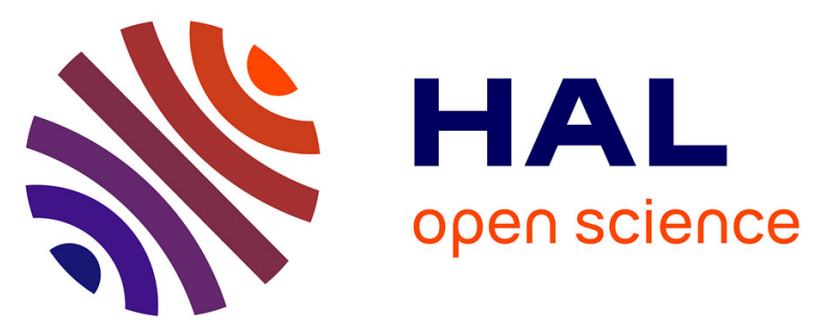

\title{
Paleoclimate reconstruction and mire development in the Eastern Great Hungarian Plain for the last 20,000 years
}

Ildikó Vincze, Walter Finsinger, Gusztáv Jakab, Mihály Braun, Katalin Hubay, Daniel Veres, Tamás Deli, Zoltán Szalai, Zoltan Szabó, Enikö K. Magyari

\section{To cite this version:}

Ildikó Vincze, Walter Finsinger, Gusztáv Jakab, Mihály Braun, Katalin Hubay, et al.. Paleoclimate reconstruction and mire development in the Eastern Great Hungarian Plain for the last 20,000 years. Review of Palaeobotany and Palynology, 2019, 271, pp.104112. 10.1016/j.revpalbo.2019.104112 . hal-02279803

\section{HAL Id: hal-02279803 https://hal.science/hal-02279803}

Submitted on 4 Nov 2020

HAL is a multi-disciplinary open access archive for the deposit and dissemination of scientific research documents, whether they are published or not. The documents may come from teaching and research institutions in France or abroad, or from public or private research centers.
L'archive ouverte pluridisciplinaire HAL, est destinée au dépôt et à la diffusion de documents scientifiques de niveau recherche, publiés ou non, émanant des établissements d'enseignement et de recherche français ou étrangers, des laboratoires publics ou privés. 


\title{
Journal Pre-proof
}

Paleoclimate reconstruction and mire development in the Eastern Great Hungarian Plain for the last 20,000 years

Ildikó Vincze, Walter Finsinger, Gusztáv Jakab, Mihály Braun, Katalin Hubay, Daniel Veres, Tamás Deli, Zoltán Szalai, Zoltán Szabó, Enikő Magyari

\author{
PII: $\quad$ S0034-6667(19)30121-6 \\ DOI: $\quad$ https://doi.org/10.1016/j.revpalbo.2019.104112 \\ Reference: $\quad$ PALBO 104112
}

To appear in: $\quad$ Review of Palaeobotany and Palynology

Received date: $\quad 29$ April 2019

Revised date: $\quad 28$ August 2019

Accepted date: $\quad 31$ August 2019

Please cite this article as: I. Vincze, W. Finsinger, G. Jakab, et al., Paleoclimate reconstruction and mire development in the Eastern Great Hungarian Plain for the last 20,000 years, Review of Palaeobotany and Palynology(2018), https:/doi.org/10.1016/ j.revpalbo.2019.104112

This is a PDF file of an article that has undergone enhancements after acceptance, such as the addition of a cover page and metadata, and formatting for readability, but it is not yet the definitive version of record. This version will undergo additional copyediting, typesetting and review before it is published in its final form, but we are providing this version to give early visibility of the article. Please note that, during the production process, errors may be discovered which could affect the content, and all legal disclaimers that apply to the journal pertain.

(C) 2018 Published by Elsevier. 


\section{Palaeoclimate reconstruction and mire development in the Eastern Great Hungarian Plain for the last 20,000 years}

Ildikó Vincze ${ }^{1,2,3^{*}}$, Walter Finsinger ${ }^{4}$, Gusztáv Jakab ${ }^{5,6}$, Mihály Braun ${ }^{3}$, Katalin Hubay ${ }^{3}$, Daniel Veres ${ }^{7}$, Tamás Deli ${ }^{8}$, Zoltán Szalai ${ }^{9,10}$, Zoltán Szabó ${ }^{10}$, Enikő Magyari ${ }^{1,3,10}$

${ }^{1}$ MTA-MTM-ELTE Research Group for Paleontology, H-1117 Budapest, Pázmány Péter str. 1/C, Hungary

${ }^{2}$ Department of Physical and Applied Geology, Eötvös Loránd University, H-1117 Budapest, Pázmány Péter str. $1 / C$, Hungary

${ }^{3}$ Isotope Climatology and Environmental Research Centre (ICER), Institute for Nuclear Research, Hungarian Academy of Sciences, H-4026 Debrecen, Bem square 18/C, Hungary

${ }^{4}$ ISE-M, University of Montpellier EPHE, IRD, Montpellier, France

${ }^{5}$ Szent István University, Faculty of Economics, Agricultural and Health Studies, H-5540, Szarvas, Szabadság str. 1-3., Hungary

${ }^{6}$ Hungarian Academy of Science - Institute of Archaeology, Research Centre for the Humanities, H-1014 Budapest, Úri str. 49., Hungary

${ }^{7}$ Institute of Speleology, Romanian Academy, Clinicilor 5, 400006 Cluj-Napoca, Romania

${ }^{8}$ biologist-researcher, H-5500 Gyomaendröd, Móricz Zs. str. 2., Hungary

${ }^{9}$ Hungarian Academy of Science - Research Centre for Astronomy and Earth Sciences, Geographical Institute, H-1112, Budapest, Budä̈rsi str. 45., Hungary

10 Department of Environment and Landscape Geography, Eötvös Loránd University, H-1117 Budapest, Pázmány Péter str. 1/C, Hungary

*Corresponding author: Ildikó Vincze, Eötvös Loránd University Department of Physical and Applied Geology, H-1117 Budapest, Pázmány Péter sétány 1/C, Hungary. Tel.: +36-1-3722500/ext. 1738.

E-mail address: ildi_vincze@yahoo.com 


\begin{abstract}
We present the reconstruction of mire vegetation changes and fire history recorded in a continuous sediment profile that spans the last 20,000 cal yr BP from the Late Pleniglacial to Holocene in North-eastern Hungary. We also aimed to reveal past climate changes by using ecological requirements of specific aquatic plants as summer temperature indicators. Our results suggest the formation of a mesotrophic mire around 20,000 cal yr BP with brown moss, Betula sp. and Selaginella selaginoides cover beside the occurrence of Phragmites australis, Typha latifolia and T. angustifolia suggesting base-rich fen and tundra-like wet-ground habitats on the lakeshore. This community shifted to reed dominated swamp at $c$. $18,300 \mathrm{cal}$ yr BP with inferred min. July temperatures of $12-15.7^{\circ} \mathrm{C}$. Pinus sp., Betula nana, B. pendula/pubescens, Hippuris vulgaris and P. australis dominated until 16,600 cal yr BP pointing to shallow muddy stagnant water and colder climatic conditions than in the preceding interval. The most warmth-demanding species, T. latifolia and T. angustifolia indicated July mean temperatures $>14-15.7^{\circ} \mathrm{C}$ soon after the LGM. The formation of biogenic carbonate also started at an early stage; major accumulation occurred between 15,200 and 10,000 cal yr BP. In the Early Holocene, environmental indicator species (e.g. Phragmites australis and T. latifolia) pointed to warmer and shallower conditions, while the late Holocene was characterised by strong eutrophication and reed swamp dominance on the lakeshore. Elevated macrocharcoal concentration, wood fragments and remains of Typha species suggested frequent local fires and dry mire surface conditions during the last 1700 years.
\end{abstract}

Keywords: plant macrofossil, vegetation reconstruction, Late Pleniglacial, Lateglacial, Carpathian Basin, Great Hungarian Plain 


\section{Introduction}

Climate warmed with varying amplitude at different latitudes after the Last Glacial Maximum (LGM: 26,500-19,000 cal yr BP according to Clark et al, 2009), followed by rapid warming at the onset of the Holocene (from $c a$. 11,700 cal yr $\mathrm{BP}$ according to Rasmussen et al., 2014). Proxies reflecting past climate change can be found in lake and mire sediments, and climate reconstructions are often based on biological proxies, such as pollen (e.g. Aarnes et al., 2012; Huntley et al., 1993, Seppä et al., 2004), chironomids (e.g. Heiri et al., 2003; Lotter et al., 1997; Tóth et al., 2012, 2015) and plant macrofossils (e.g. Björkman et al., 2003; Feurdean, 2005; Feurdean et al., 2007b; Feurdean and Bennike, 2004; Jakab et al., 2005; Magyari et al., 1999, 2009, 2012a, 2008). In general, these paleoclimate records reflect the pronounced climatic fluctuation also detected in the Greenland ice-core stable isotope data (Rasmussen et al., 2014) and provide major information about the long-term variability of climate. Relatively few biological proxy records exist for the Late Pleniglacial (LPG: 24,00014,600 cal yr BP) across Europe (e.g. Binney et al., 2017; Gobet et al., 2010; Kaltenrieder et al., 2009). Some pollen and plant macrofossil studies are available from North-eastern (Alm and Birks, 1991; Heikkilä et al., 2009; Wohlfarth et al., 2006) and East-Central Europe (Björkman et al., 2003; Feurdean et al., 2007; Jankovska \& Pokorný, 2008; Magyari et al., 1999, 2012a, 2014; Pokorný, 2002; Wohlfarth et al., 2001), and they mostly indicate the scattered presence of trees in East-Central and Southern Europe during the LPG (Galka et al., 2014; Tantau et al., 2006; Tonkov et al., 2011; Tzedakis et al., 2013; Willis et al, 2000a; Willis and van Andel, 2004). In addition, several multiproxy records cover the LPG and Lateglacial in Poland (e.g. Fajer et al, 2012; Gałka \& Sznel, 2013; Kołaczek et al., 2015; Milecka et al, 2011), in the Czech Republic (Engel et al., 2010; Rybníček \& Rybníčková, 1968; Pokorný, 2002; Pokorný et al., 2010) and in Romania (Björkman et al., 2003; Feurdean 
et al., 2007; Magyari et al., 2009, 2012a, 2014a). There are particularly few sites in Hungary where the LGM and the early period after the Last Glacial Maximum have been studied by Medzihradszky \& Bajzáth (1998), Magyari et al. (1999), Jakab et al. (2005) and Rudner \& Sümegi (2001).

Pollen-based summer temperature reconstructions are predominantly driven by changes in the major arboreal and non-arboreal pollen taxa (Seppä et al., 2004) and in case of large lakes with large pollen source area they presume that the pollen record reflects the regional vegetation and therefore regional climate change (Seppä et al., 2004; Whitmore et al., 2005). In addition, low taxonomic resolution is a serious limiting factor in case of the pollen based reconstructions, as pollen grains are infrequently identifiable to species level (Ortu et al, 2006; Seppä et al., 2004). This is especially critical in pollen based temperature reconstructions when trees are rare or even absent in the study area (Aarnes et al., 2012). Many early studies recognised that the aquatic plant remains may provide more accurate temporal records of climate change due to their rapid dispersal rates. Backman (1948, 1935), Iversen (1954), Samuelsson (1934) and Szafer (1954, 1946) studied first the Pliocene aquatic flora in Europe and recognized that aquatic plant remains can provide a more accurate record of past climate change due to their rapid dispersal rates. Aquatic plants respond quicker to climate change than trees and terrestrial herbs making them an ideal target mainly for July mean temperature reconstructions as demonstrated recently for the boreal zone in Fennoscandinavia (Väliranta et al., 2015a) and for Europe by Schenk et al. (2018).

Quantitative reconstructions of past climate using aquatic plant macrofossils are predominantly available from high latitudes or high altitudes and from temperate regions (e.g. Luoto et al., 2014; Rybníček \& Rybničková, 1968; Schenk et al., 2018; Väliranta et al., 2006) probably due to the poorly examined broad-scale dispersal dynamics and indicator value of aquatic plants (Väliranta et al., 2015a). In contrast to the pollen-based reconstructions, 
macrofossil studies can use the information about the presence of individual indicator taxa in the local macrofossil assemblages and their ecological requirements (based on modern distribution ranges) to reconstruct past climate and vegetation changes (Väliranta et al., 2015a). Plant macrofossils are valuable to display the local presence of various taxa, however the method also has its own drawback, namely the absence of macrofossils in a sediment record does not necessarily mean the species was absent locally (Birks et al., 2011).

Last glacial maximum climate variability in the Carpathian Basin was inferred mainly by sedimentological (Bradák et al., 2011) and malacological investigations of loess and occasionally lake sediments (Hupuczi et al., 2006; Sümegi \& Krolopp, 2002; Sümegi et al, 2013, 2018). Past vegetation development and composition was studied by Feurdean et al. (2008b, 2007a, 2007b, 2013), Magyari (2002, 2015), Magyari et al. (1999, 2014a); Medzihradszky and Bajzáth (1998), Sümegi et al. (2013) and Willis et al. (1995; 1997) among others. These studies have progressively increased our knowledge on the LPG vegetation characteristics, with increasing evidence on tree refugia in the Carpathian Basin and mosaic boreal environment in which typical wet tundra habitats also prevailed with their characteristic herbs (e.g. Dryas octopetala, Betula nana, Warnstorfia sarmentosa). The vegetation studies that cover the LPG and LGM are based on plant macrofossils (Willis and Van Andel, 2004a), charcoal (Rudner \& Sümegi, 2001; Willis et al., 2000) and pollen evidence (Engel et al, 2010; Jankovska \& Pokorný, 2008; Rybníček and Rybníčková, 1968, Pokorny et al., 2002, 2010). According to these studies, the LPG landscape of the GHP was characterised by coniferous (Pinus sylvestris, P. cembra, Picea abies, Larix) and cold deciduous trees, such as Betula sp., Salix and Populus with grass steppe species mainly on the southern part (Magyari et al., 2014b; Sümegi et al., 2013b), while some other deciduous taxa were also described from the NE-part of the GHP (Magyari et al., 1999; Rudner and Sümegi, 2001; Willis et al., 2000; Willis and Van Andel, 2004). During cold periods continental cold 
steppe elements became dominant (Járainé-Komlódi, 1969; Kasse et al., 2010; Sümegi \& Krolopp, 1995; Sümegi et al., 1998, 2002).

So the general picture is relatively well known by now, however the regional differences and the aquatic vegetation are less well-known. Therefore, in this paper we focus on the reconstruction of mire vegetation succession during the last glacial termination and partly also during the Holocene as recorded in a $635 \mathrm{~cm}$-long sediment sequence from Northeastern Hungary. We investigated this sediment archive to address the following questions: (1) How did the local vegetation change at Kokad mire during the last 20,000 years? (2) How did the local vegetation react to Heinrich event-1 (HE-1)? (3) What were the characteristics of the climate during the LPG and LG period? (4) What were the main characteristics of the local LPG, LG and Holocene fire histories in comparison with other parts of Central and EastCentral Europe?

For answering these questions, we use the indicator value of aquatic plants and their ecological tolerance limits to reconstruct climate change during the last 20,000 years, focusing especially on the Heinrich 1 (HE-1) cooling interval around 16,800 cal yr BP (according to Bond et al. (1997), GS-2.1a in NGRIP, Rasmussen et al. (2014). The investigation was carried out at Kokad mire, which is situated ca. $4 \mathrm{~km}$ west of the Hungarian-Romanian border in the Great Hungarian Plain (Figure 1). The palaeobotanical data include plant macrofossil, macrocharcoal, malacological analyses; these results together with the geochemistry, particle-size distribution and radiocarbon dating are used to reconstruct the past environment and climate change together with the fire history around the former lake. 


\section{Study area}

Kokad Mire $\left(47^{\circ} 24^{\prime} 10^{\prime} \mathrm{N}, 2^{\circ} 55^{\prime} 43^{\prime} \mathrm{E}\right.$; $112 \mathrm{~m}$ a.s.l.) is situated in the Érmellék Region of Eastern Hungary (Figure 1) that is characterised by temperate continental climate with annual mean temperature $9.8^{\circ} \mathrm{C}$ and mean annual precipitation $568 \mathrm{~mm}$ (average values for Debrecen meteorological station between 1901-2000), July mean temperature is between 19$20^{\circ} \mathrm{C}$ and January mean temperatures are $\sim-3^{\circ} \mathrm{C}$. The predominant wind direction is northeastern; however, the less frequent westerlies are stronger (Kiss et al., 2012). The landscape is characterised by different vegetation types: dry and mesic grasslands, mesotrophic wet meadows, hardwood forests and closed steppic oak forests are the most frequent (Király et al., 2008). Mires and mesic habitats are often occupied in Érmellék by Angelica palustris, Veratrum album, Berula erecta, Carex appropinquata, Carex elata, Hypericum tetrapterum and Ranunculus lingua (Király et al., 2008).

The mire is located at the boundary of Kokad village (Figure 1). It sits at the border of the alluvial plain of Érmellék and the sand-covered alluvial fan complex called Nyírség. During the Weichselian glaciation (around 46,000 $\pm 4000-39,000 \pm 4000$ cal yr BP) the PaleoTisza river shifted towards the Érmellék, and eroded the floodplain (Kiss et al., 2015). The intensifying subsidence of the Bodrogköz area (Figure 1) and the uplifting of the Érmellék and Nyírség regions forced the river to leave the centre of the GHP and turn northward. The river changed its course towards the subsiding Szatmár-Bereg Plain (Borsy, 1989), although the exact timing of the Tisza River avulsion is still uncertain. According to Borsy (1989), it occurred between 22,000-20,000 cal yr BP, while other studies proposed a shift to the present channel at 18,000-16,000 cal yr BP (Timár et al., 2005), or even later, around 14,000 years ago (Gábris and Nádor, 2007). The present vegetation at the coring location is dominated by reed (Phragmites australis) with Typha angustifolia, T. latifolia and Sparganium erectum (Papp et al., 2010). 


\section{Material and methods}

\section{Sediment sampling and lithology}

The $635 \mathrm{~cm}$-long sediment core was taken in the centre of the mire $\left(47^{\circ} 24^{\prime} 10^{\prime \prime} \mathrm{N}\right.$, $\left.21^{\circ} 55^{\prime} 43^{\prime \prime} \mathrm{E}\right)$ in 2008 . We used a Livingstone piston corer for the upper $600 \mathrm{~cm}$ and a Russian corer for the lowermost $40 \mathrm{~cm}$. Sediment composition was described in the laboratory using the Troels-Smith system (Troels-Smith, 1955) (Table 1), cores were stored at $4^{\circ} \mathrm{C}$.

"insert Table 1"

\section{Chronology}

The chronological framework of the Kokad-2 core was established using a series of 23 AMS ${ }^{14} \mathrm{C}$ age determinations at the Poznan Radiocarbon Laboratory (Poland) and at the Isotope Climatology and Environmental Research Centre (ICER, Debrecen, Hungary) (Table 2). The dating was made on plant remains (Phragmites australis stems, Cyperaceae leaves, Carex sp. leaves, Betula nana fruit and Sambucus sp. seeds, wood fragments), macrocharcoal particles and biogenic carbonate material, the latter taken between 239 and $279 \mathrm{~cm}$ (Table 2). All ${ }^{14} \mathrm{C}$ ages were calibrated into calendar years using the Calib Rev. v. 7.0.4. software and the IntCal13 radiocarbon calibration curve (Reimer et al., 2013; Stuiver \& Reimer, 1993). The age-depth model was constructed using the Bayesian method (Blaauw and Christen, 2013) with the BACON package in R (Figure 2). For testing the accuracy of our age-depth model, pollen results from Kokad and other sites as Nagymohos, Lake Fehér and Lake St Anne were also taken into consideration (see Appendix B). 


\section{Magnetic susceptibility, bulk density and organic content}

Core segments were split into two halves in the laboratory. One core half was photographed, described, and used for magnetic susceptibility measurements (MSCL) with a core logger at 5-mm resolution. The other half core was cut continuously into $1-\mathrm{cm}$ wide half cylinders. One $\mathrm{cm}^{3}$ sub-samples were taken at $2-\mathrm{cm}$ intervals, dried at $105^{\circ} \mathrm{C}$ for 2 hours, followed by ignition at $550^{\circ} \mathrm{C}$ for 3 hours (Heiri et al., 2001). Wet weight, dry weight and weight loss-on-ignition (LOI) were determined and used to estimate bulk density and organic content.

\section{Geochemistry and grain size analyses}

Geochemical analyses were carried out to provide additional evidence for the physicochemical changes in the mire as well as in the catchment area. Samples of $1-\mathrm{cm}^{3}$ were taken at 4-cm intervals for major element analyses. The chemical extraction technique followed Berglund (1987) and Bengtsson \& Enell (1986). A two-step extraction was used: first, dried samples were digested using $65 \% \mathrm{HNO}_{3}$ at $80^{\circ} \mathrm{C}$ for $3 \mathrm{~h}$. The samples were treated with $35 \%$ $\mathrm{H}_{2} \mathrm{O}_{2}$ and evaporated at $80^{\circ} \mathrm{C} . \mathrm{HNO}_{3}(1 \%)$ was used to dissolve the extractants. For completing the dissolution process, samples were placed into ultrasonic bath. Thereafter, samples were dried at $105^{\circ} \mathrm{C}$, and then heated in closed reagent tubes at $105^{\circ} \mathrm{C}$ for $2 \mathrm{~h}$ with $38 \%$ HF. After cooling, boric acid (5\%) was added and the tubes were filled up to $10 \mathrm{ml}$ using double de-ionised water. Element concentrations were measured using inductively coupled plasma atomic emission spectrometry (ICP-AES) at the ICER Laboratory, Debrecen (Hungary). Results are presented in Figure 3.

Grain-size distributions were determined at $4-\mathrm{cm}$ intervals with chemically pre-treated samples, following Buurman et al. (1996). The two-step treatment involved treatments with 
sodium acetate solution $(1 \mathrm{M})$ and acetic acid $(100 \%)$ to remove carbonates, and hydrogen peroxide $(35 \%)$ to digest organic matter. Samples with high organic content were heated at $105^{\circ} \mathrm{C}$ for $2 \mathrm{~h}$. All samples were measured at the Department of Environmental and Landscape Geography, Eötvös Loránd University, Budapest using a Horiba Partica LA950V2 laser particle-size analyser. The grain-size distributions were combined from the datasets using Blott \& Pye (2012). For determining the silt/clay size class boundary the method of Eshel et al. (2004) and the Horiba Inc. (2012) was applied and the following classes were used: coarse sand >0.5 mm; medium sand $0.5-0.2 \mathrm{~mm}$; fine sand $0.2-0.1 \mathrm{~mm}$; very fine sand 0.01-0.05 mm; coarse silt $0.05-0.01 \mathrm{~mm}$; fine silt $0.01-0.005 \mathrm{~mm}$; clay $<0.005 \mathrm{~mm}$ (Figure 3).

\section{Mollusc analysis}

During the plant macrofossil analysis, mollusc shells were selected and classified into ecological and biogeographical groups following Sümegi and Krolopp (2002). The fauna was divided into species requiring steady water cover (ditch group), species tolerant to periodic water supply (slum species), species living in water or in very moist environment (hygrophilous species) and species avoiding the extremes of moisture or dryness (mesophylous). Molluscs were also grouped according to their recent geographical distribution, and on the basis of their palaeoclimatological indicator role (Figure 4B and Table 4).

\section{Plant macrofossil analysis}

For plant macrofossil analysis 5 -cm wide sub-samples (average volume $23 \mathrm{~cm}^{3}$ ) were taken contiguously. Samples were briefly soaked in $10 \% \mathrm{NaOH}$ and wet-sieved through 250 
$\mu \mathrm{m}$ mesh. Terrestrial and aquatic plant remains were picked out systematically from the residues under a stereomicroscope (Olympus SZ 51, at x10 magnification) and identified to the lowest possible taxonomic level using identification keys (Bojnanský \& Fargašová, 2007; Haas, 1994; Katz et al., 1965, Schermann, 1967; Smith, 2004; Tomlinson, 1985; Velichkevich \& Zastawniak, 2008) and by comparison with the reference collection of the MTA-MTMELTE Research Group for Paleontology.

Sediment components (e.g. unidentifiable organic material (UOM), wood, macrocharcoal, unidentifiable leaf fragments (ULF), undifferentiated monocotyledon remains) were counted in 5 randomly chosen $1-\mathrm{cm}^{2}$ squares in the Petri dish. Estimates were made of the relative frequency of the components amongst the indeterminate fossils, as leaf and bryophyte fragments (ULF, UBM), monocotyledons, macrocharcoal particles and unidentifiable organic material (UOM) following Jakab et al. (2004). Few samples from different sediment layers were selected to identify brown moss species. The concentrations of plant macrofossils were standardised to $40 \mathrm{~cm}^{3}$ sediment and diagrams were drawn using the TILIA software (Grimm, 1992). The plant macrofossil concentration diagram was divided into seven macrofossil assemblage zones (K-M1 to K-M7) visually taking into account major compositional and concentration changes.

The reconstruction of mean July temperatures relies on aquatic and terrestrial climate indicator-species extracted from the sediment. Their minimum and optimum mean July temperatures were previously published in Kolstrup (1980), Hannon \& Gaillard (1997) and Schenk et al. (2018). These published temperature values were applied to the mean July temperature reconstruction at Kokad mire for the last 20,000 years.

\section{Macrocharcoal analysis}


For macrocharcoal analysis, 565 samples of $1 \mathrm{~cm}^{3}$ were taken contiguously, deflocculated and bleached using $10 \%\left(\mathrm{NaPO}_{3}\right)_{6}$ and $5 \% \mathrm{NaOCl}$ and sieved through a $160 \mu \mathrm{m}$ mesh under a soft water jet following Genries et al. (2012). The residue was washed into a white porcelain-evaporating dish to aid identification of charcoal particles. The material was examined under a binocular microscope (Leica M80 at X60 magnification) equipped with a video camera. The WINSEEDLE image-analysis software (Regent Instruments Canada Inc., 2009) was used to count the macrocharcoal particles and measure their surface area. Charcoal concentrations (by number and by area) were transformed into charcoal influx (or accumulation rate, CHAR).

To reconstruct fire history, the $\mathrm{CHAR}_{\text {count }}$ record was first interpolated to a constant sediment-accumulation rate $\left(\mathrm{CHAR}_{\mathrm{i}}\right)$ and thereafter decomposed into the background $\left(\mathrm{CHAR}_{\text {background }}\right)$ and peak $\left(\mathrm{CHAR}_{\text {peak }}\right)$ components. The $\mathrm{CHAR}_{\text {background }}$ should reflect regional biomass burning and secondary charcoal deposition, and $\mathrm{CHAR}_{\text {peaks }}$ record should

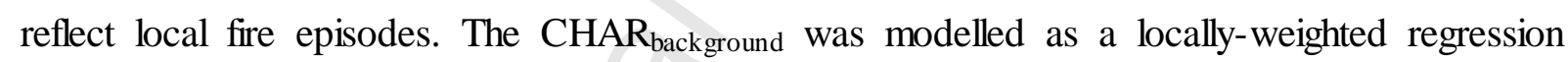
(lowess regression) with 1000-year time window, which was found to maximise the signal-tonoise ratio (SNI) (Kelly et al., 2011). The $\mathrm{CHAR}_{\text {peak }}$ component was obtained by subtracting the $\mathrm{CHAR}_{\text {background }}$ from $\mathrm{CHAR}_{\mathrm{i}}$. $\mathrm{CHAR}_{\text {peak }}$ values exceeding the $90^{\text {th }}$ percentile threshold of the modelled local-noise distribution were identified as potential fire episodes $\left(\mathrm{CHAR}_{\mathrm{fire}}\right)$. These were finally screened using the minimum-count test (Higuera et al., 2010). We used the distribution of fire return intervals (years per fire; FRIs) for the LGM $(20,000-15,000$ cal yr BP) and the late Holocene (4000-0 cal yr BP) to characterise the temporal characteristics of fire regimes for each of these time periods. FRI distributions were described by the mean and median FRI (FRI mean and FRI median, respectively). We tested whether the smoothing window width had an influence on FRIs using Weibull test, as implemented in the CharAnalysis software (Higuera et al., 2009). 


\section{Results}

"insert Figure 2"

\section{Chronology}

Of the $23{ }^{14} \mathrm{C}$ age determinations (Table 2) five samples $(4 \mathrm{~cm}, 78 \mathrm{~cm}, 123 \mathrm{~cm}, 244 \mathrm{~cm}$ and $601 \mathrm{~cm}$ ) contained very low amount of carbon, and three of them were considered to be outliers according to the Bayesian model (Figure 2). Many of these five ${ }^{14} \mathrm{C}$ ages showed younger ages than expected probably due to low carbon content and consequent contamination by modern $\mathrm{CO}_{2}$ during the dating. These younger dates generally originate from samples with small sample weight and large surface area.

For running the age-depth model (Figure 2) the surface of sediment was determined -58 cal yr BP old (AD 2008), while the bottom of the studied sediment section is around 20,000 cal yr BP (Figure 2). Nine ${ }^{14} \mathrm{C}$ dates were identified as outliers in this model (Table 2). The age-depth model suggests the lowest sediment deposition times (average $14 \mathrm{yr} \mathrm{cm}^{-1}$ ) between 20,000 and 15,000 cal yr BP $(275-635 \mathrm{~cm})$ for the predominantly clayey-silty sediment with occasional sand and charcoal layers, then slower deposition with larger deposition times (average $59 \mathrm{yr} \mathrm{cm}^{-1}$ ) between 15,000 and $3400 \mathrm{cal} \mathrm{yr} \mathrm{BP} \mathrm{(100-275} \mathrm{cm)} \mathrm{for} \mathrm{the} \mathrm{grey-greenish}$ clayey lime. Sediment deposition times decreased (average $32 \mathrm{yr} \mathrm{cm}^{-1}$ ) for the brownish peat in the top $100 \mathrm{~cm}$ (last 3400 years) suggesting more rapid sediment accumulation.

An alternative age-depth model was also developed, which excluded the less reliable bulk sediment dates and therefore gave significantly younger ages during the Early Holocene section of the core. Our actual chronology is supported by two significant marker horizons in 
the pollen record (Appendix B). The rapid decrease of Cyperaceae (both pollen and macrofossils) together with the decline in $\mathrm{Fe}, \mathrm{Mn}, \mathrm{Ca}$ concentrations, and major decrease in fine sand content at around 16,200 cal yr BP coincide well with detected climate and ecosystem changes at other sites and various loess records (Sümegi, 2005), the Black Sea sediment (Kwiecien et al., 2009; Major et al., 2006; Sanchi et al., 2014), and Lake St Anne (Magyari et al., 2014a, 2019 under revision; Tóth et al., in prep) and even Southern Alps sediment records (Tinner et al, 1999) indicate rapid ecosystem reorganization at that time. The other pollen horizon marks the onset of Holocene around 11,700 cal yr BP, when the rapid pollen percentage increase of Ulmus, Quercus and Corylus is generally noticeable in this region (Appendix B).

"insert Figure 3"

\section{Sediment lithology, organic content and magnetic susceptibility}

Seven lithostratigraphic units were determined in the 635-cm long core (Table 1, Figure $3 \& 4 A B)$. Sediments comprising the lowermost two units (635-600 cm and 600-595 cm; 20,000-19,500 cal yr BP) were deposited directly after the last glacial maximum (LGM), in the Late Pleniglacial period ( GS-2.1; Rasmussen et al., 2014). The sediment is grey clayey silt with frequent black, seemingly burnt layers. This is followed by darker, brownish coloured silty clay between 595 and $400 \mathrm{~cm}(19,500-16,500 \mathrm{cal}$ yr BP) and mid-brown clayey sandy silt with occasional carbonate precipitation $(400-300 \mathrm{~cm} ; 16,500-15,300$ cal yr BP). Organic content values are low at the bottom, between 3 and 6\%, with two moderately higher peaks (c. 11\%) at $458 \mathrm{~cm}$ and $484 \mathrm{~cm}(17,500 \mathrm{cal} \mathrm{yr} \mathrm{BP}$ and 17,100 cal yr BP) (Figure 3), then further decrease above $400 \mathrm{~cm}$ to $<5 \%$ until the Holocene. The fifth unit represents the Lateglacial (300-213 cm; 15,300-10,800 cal yr BP) and the sediment is lime rich clay with 
abundant mollusc shell remains. The clayey silt unit between 213 and $72 \mathrm{~cm}(10,800-2300$ cal yr BP) represents the majority of the Holocene with higher organic content (increase up to $21 \%$ at $151 \mathrm{~cm} ; 6100 \mathrm{cal} \mathrm{yr} \mathrm{BP})$ and rich in plant remains. Finally, the top unit $(72-0 \mathrm{~cm}$; 2300 cal yr BP to present) is blackish brown reed-swamp peat rich in mollusc shells, and organic content reaches maximum value of $88 \%$ at $50 \mathrm{~cm}(1600 \mathrm{cal} \mathrm{yr} \mathrm{BP})$.

Magnetic susceptibility (MS, Figure 3) values are very low between 542 and $468 \mathrm{~cm}$ (18,500-17,500 cal yr BP). Strongly fluctuating and high values occur between 468 and 422 cm (17,500-16,800 cal yr BP) suggesting increased input of magnetic minerals with strong variation, then a gradual decrease starts from 16,800 cal yr BP $(422 \mathrm{~cm})$ although values still strongly fluctuate until $361 \mathrm{~cm}(16,100 \mathrm{cal} \mathrm{yr} \mathrm{BP})$. Between 361 and $243 \mathrm{~cm}(16,100-13,600$ cal yr BP) MS values are still relatively high, but show a gradual decreasing trend. Lowest MS values were recorded above $243 \mathrm{~cm}(<13,600 \mathrm{cal}$ yr BP) (Figure 3). MS values increase modestly around $149 \mathrm{~cm}(6000 \mathrm{cal} \mathrm{yr} \mathrm{BP})$, show increases at $118 \mathrm{~cm}(3900 \mathrm{cal} \mathrm{yr} \mathrm{BP})$ and moderately elevated values occur between 77 and $64 \mathrm{~cm}(2400-2000$ cal yr BP). Finally, MS values re-increase slightly in the topmost $10 \mathrm{~cm}$, which covers the last $c .300$ years.

\section{Major element and grain-size analyses}

The results of the geochemical and grain-size analyses show (Figure 3) that both Fe and Mn concentrations are relatively high and fluctuate from the bottom of the core to $320 \mathrm{~cm}$ $(20,000-15,700$ cal yr BP). High percentages of coarse silt and very fine sand characterise this interval together with strong fluctuation in the MS curve. At $365 \mathrm{~cm}(16,170 \mathrm{cal} \mathrm{yr} \mathrm{BP})$ both $\mathrm{Fe}$ and $\mathrm{Mn}$ show peak concentrations while organic content shows a small increase together with the increase of $\mathrm{Ca}$, the sudden decrease in coarse silt and very fine sand content that is compensated by an increase in fine silt. Since neither medium sand, nor MS and $\mathrm{Ca}$ 
values return to the previous level, and the sediment composition also changes (from 16,500 cal yr BP), these abrupt changes are likely indicative of a rapid environmental shift involving the accelerated input and precipitation of $\mathrm{Ca}$ in the lake and less intense erosion. $\mathrm{Ca}$ values show steep increase again at $292 \mathrm{~cm}(15,280 \mathrm{cal}$ yr BP). Significantly higher coarse silt and fine silt values characterise the core from $375 \mathrm{~cm}(16,300 \mathrm{cal} \mathrm{yr} \mathrm{BP})$ to the top with many fluctuations (decreases in coarse fraction at $300 \mathrm{~cm}(15,400 \mathrm{cal} \mathrm{yr} \mathrm{BP}) ; 220 \mathrm{~cm}(11,570 \mathrm{cal} \mathrm{yr}$ BP); 125 cm (4280 cal yr BP); $100 \mathrm{~cm}$ (3400 cal yr BP); $75 \mathrm{~cm}(2370$ cal BP); $50 \mathrm{~cm}$ (1600 cal yr BP). Fe/Mn ratios start to decrease from $370 \mathrm{~cm}(16,200$ cal yr BP); this decrease is mainly attributable to the selective increase of Mn between 290 and $220 \mathrm{~cm}(15,250-11,560$ cal yr BP) that is accompanied by massive increase in $\mathrm{Ca}$ and modest increase in $\mathrm{S}$ concentrations. High $\mathrm{Ca}$ values suggest strong biogenic carbonate precipitation between 292 and $206 \mathrm{~cm}(15,250-10,040 \mathrm{cal}$ yr BP). The upper $75 \mathrm{~cm}$ (last 2400 years) is characterised by prominently high $\mathrm{S}$ values simultaneously with maximum values of organic content and strongly fluctuating but high $\mathrm{Ti}$ values (at $55 \mathrm{~cm}$ with absolute maximum). These records suggest that the detected peak of coarse sand at $50 \mathrm{~cm}(c .1600$ cal yr BP) might be an error during the grain-size measurement, where clumped organic debris was probably measured.

\section{Plant macrofossil and mollusc analyses}

"Insert Figure 4A and 4B"

High concentration of woody fragments (mainly Betula sp. remains), ostracod, Coleoptera, bryophyte remains (mainly Pseudocalliergon trifarium and Drepanocladus aduncus) and Daphnia magna and D. pulex ephippia characterise the bottom of the sediment between 635-605 cm (zone K-M1; 20,000-19,700 cal yr BP; Figure 4A and 4B, Table 3).

Phragmites australis, Typha angustifolia and T. latifolia remains were detected first at 615 
cm (c. 19,900 cal yr BP). In addition, seeds of several wetland species occurred, such as Carex sp., Sparganium minimum, cf. Juncus and Eleocharis sp. Megaspores of Selaginella selaginoides were also abundant in this early stage.

The continuous presence of Phragmites australis rhizomes was detected from $524 \mathrm{~cm}$ (c. 18,300 cal yr BP) in zone K-M2 (605-500 cm, 19,700-17,900 cal yr BP). Daphnia magna/D. pulex ephippia, monocotyledon remains and woody fragments were also abundant in this interval. Occasional occurrence of Betula sp., Potamogeton natans and T. angustifolia seeds was typical in this zone, while megaspores of $S$. selaginoides disappeared at $518 \mathrm{~cm}$ (18,200 cal yr BP). Macrocharcoal particles counted among the plant remains (Figure 4A) showed fluctuating values from zone K-M2 to K-M4a. However, non-charred woody fragments were abundant in macrofossil assemblage zones K-M1 and K-M2 (Figure 4A). Aquatic mollusc species, such as the ubiquitous Planorbis planorbis support an increase in water-level in this zone (c. 19,000 cal yr BP; Figure 4B).

From 17,900 cal yr BP (zone K-M3; 500-400 cm) ostracod shells became abundant, while the concentration of macrocharcoal and woody fragments decreased. Remains of Daphnia sp. disappeared from the record at $433 \mathrm{~cm}(c .17,000 \mathrm{cal} \mathrm{yr}$ BP). The dominance of P. australis and Hippuris vulgaris characterised this interval until 16,600 cal yr BP $(400 \mathrm{~cm})$. Seeds of Betula nana, Betula cf. B. pendula/pubescens, needle bases of Pinus sp. and Carex cf. C. acutiformis occurred. From $400 \mathrm{~cm}$ (zone K-M4a; c. 16,600 cal yr BP), the sediment contained less macrofossils until $200 \mathrm{~cm}($ c. $9500 \mathrm{cal} \mathrm{yr} \mathrm{BP})$. The concentration of $P$. australis vegetative remains was also low in this period, while wood fragments disappeared. Simultaneously with the low concentration of plant remains, high concentration of mollusc shells and the presence of Chara vulgaris oogonia can be noted in subzone K-M4b (315-210 $\mathrm{cm}, 15,600-10,500$ cal yr BP) that represents the Lateglacial and the earliest part of the Holocene. 
The abundance of $P$. australis increased again in zone K-M5 $(210-120 \mathrm{~cm}, 10,500-$ 3950 cal yr BP). This zone encompasses the early and mid-Holocene, when sediment accumulation rates were very low (Figure 2). Chara vulgaris and Tolypella prolifera concentrations peaked at $130 \mathrm{~cm}$ (4700 cal yr BP). Rhizomes of Typha sp. were also found in low abundance. From $125 \mathrm{~cm}(c .4200 \mathrm{cal}$ yr BP) the sediment contained more plant remains: Daphnia sp. ephippia, Typha sp. (both T. angustifolia and T. latifolia) and Potamogeton natans seeds re-appeared. The next zone boundary was drawn at 3950 cal yr BP (zone K-M6; 3950-1700 cal yr BP), when the above mentioned taxa became even more abundant, and new taxa, such as Sambucus nigra, Urtica dioica and cf. Cyperus sp. remains also appeared in high concentration, while Eupatorium cannabinum appeared in low rate.

The topmost part of the sediment sequence (K-M7; from 1700 cal yr BP) is characterised by high concentration of $P$. australis and Typha sp. rhizomes. T. angustifolia seeds became dominant, while S. nigra decreased. Remains of E. cannabinum were still present, while seeds of Rumex hydrolapathum and Myriophyllum spicatum appeared in the top $50 \mathrm{~cm}$ of the core. Mollusc elements preferring more eutrophic conditions, such as Valvata cristata and Segmentina nitida were detected at 1400 cal yr BP. Other mollusc species indicative of terrestrial habitats (as thermophilous Vallonia enniensis and mesophylous V. pulchella) were more abundant in zone K-M7 (last 1300 years) likely indicating lower water-level and drier conditions in and around the mire (Figure 4B). Wetdamp habitat preferring species such as Carychium minimum, Succinella oblonga and Zonitoides nitidus were also detected in the upmost macrofossil zone.

"insert Table 3"

"insert Table 4" 


\section{Fire-history reconstruction}

Both charcoal concentration and $\mathrm{CHAR}_{\text {background }}$ values are very low or charcoal fragments were absent in samples between 15,200 and 4200 cal yr BP. Charcoal

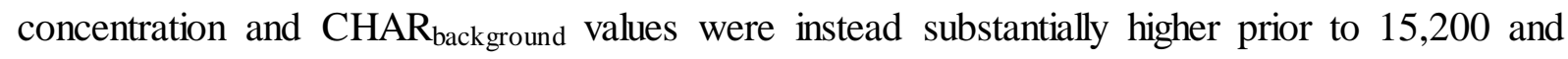
after 4200 cal yr BP, suggesting high biomass-burning rates during the LPG and the late Holocene. In keeping with this, high peak-magnitude values as well as significant charcoal peaks cluster in the LPG and the late Holocene. Fire-episode frequency reached higher values in the LPG (up to 4 fire episodes $1000 \mathrm{yr}^{-1}$ ) than in the late Holocene (up to $c a .2$ fire episodes $1000 \mathrm{yr}^{-1}$ ). To check if the FF values were significantly different, minimum count $\mathrm{P}$ tests were applied and set to 0.05 . To test whether the change of smoothing window width has any influence on FRIs we used Weibull test: the mean FRIs in Zone 1 are consistently longer than in Zone 3. During the past 4000 years the FRIs were shorter than during the LPG. However, the $95 \%$ confidence-interval distributions of the FRIs within the two zones overlap, the difference is possibly minor.

During the late Holocene, $\mathrm{CHAR}_{\text {background }}$ values peak twice (at $c a .3500 \mathrm{cal} \mathrm{yr} \mathrm{BP}$ and at ca. $1500 \mathrm{cal}$ yr BP), indicating two distinct biomass-burning phases (Figure 5). The peak around 3500 cal yr BP overlaps with the maximum concentrations of Typha sp. and Sambucus nigra remains. While around 1500 cal yr BP only Typha angustifolia and T. latifolia were frequent, the organic content reached its maximum earlier, around $1600 \mathrm{cal} \mathrm{yr} \mathrm{BP.} \mathrm{The} \mathrm{last}$ 4200 years were characterised by higher biomass-burning rates, although the wood fragments only became abundant later, during the last 2000 years in the sediment.

"insert Figure 5"

\section{Discussion}




\section{Macrofossil -inferred climate, vegetation and environmental conditions during the last}

\section{0,000 years}

"insert Table 5"

"insert Figure 6"

For reconstructing the evolution of mire and lake succession, individual indicator taxa were used, focusing on their minimum and optimum July mean temperatures (Table 5). Although this method previously provided valuable information for Northern European records (e.g. Väliranta et al., 2015) and in the global climate simulations for the Younger Dryas (Schenk et al, 2018), we had relatively few July temperature indicator taxa in the Kokad plant macrofossil record with specific ecological requirements: Hippuris vulgaris, Myriophyllum spicatum, Myriophyllum verticillatum, Typha latifolia, T. angustifolia, Potamogeton sp., Littorella sp. and Betula species as B. nana, B. pendula and B. pubescens. As we will see in the discussion below, our mean July temperature reconstruction based on the presence/absence of these species is limited due to the minimum July temperature requirements of these species that were likely often exceeded in the LPG period. This is because the Great Hungarian Plain was situated in the periglacial zone with continental climate throughout the LPG involving relatively warm summers even during maximum cooling as inferred from loess mollusc assemblages (Sümegi \& Gulyás, 2004; Sümegi, 2005). Therefore, the aquatic indicator taxa with minimum July mean temperature requirements ranging $10-16.1^{\circ} \mathrm{C}$ are within a range that was exceeded relatively early during the LPG and LG (Lateglacial) warming stages. 
At the onset of the mire formation, between ca. 20,000 and 18,000 cal yr BP the possible presence of the heliophilous and cold-tolerant shrub, Betula nana, and lesser clubmoss (Selaginella selaginoides) megaspores suggest damp, poorly vegetated fen-like habitats on the lakeshore. This inference is also supported by the presence of brown mosses: Pseudocalliergon trifarium is typical in base-rich northern mires today, more rarely over wet rock slabs and in mountainous areas mainly in montane and Northern Europe (Atherton et al., 2010; Hedenas, 1994; Smith, 2004), while Drepanocladus aduncus is a species locally abundant in lowland ditches and fens in Northern Europe, mainly in clayey areas (Atherton et al., 2010) and often in areas where the ground water is base-rich and eutrophic (Hedenas, 1994; Smith, 2004). Their presence support the presence of fen habitats. S. selaginoides often occurs together with shrub Betula species in arctic and high alpine habitats today (Eurola et al., 1984). Their co-occurrence indicates that in the Kokad area neutral or alkaline tundra-like wet-ground habitats were characteristic directly after the last glacial maximum (LGM). Remains of Betula species became frequent between 18,000 and 16,600 cal yr BP, while remains of Pinus sp. were only detected during this early phase, implying to their local presence. During the early LPG, the development of boreal forest-steppe vegetation was also detected at the nearby Bátorliget (Figure 1) with the regional presence of Pinus sp. (Sümegi and Juhász, 2004). Boreal woodland expansion was also recorded around 19,000 cal yr BP at Lake Fehér (south of Kokad mire) with Pinus Dyploxylon-type and Picea abies together with broadleaved species (Sümegi et al., 2013). These findings are in line with our Betula sp. and Pinus sp. remains despite the distance of $170-\mathrm{km}$ between the sites. Other palaeobotanical evidences confirmed mosaic-like pattern of the environment by charcoal pieces of Picea, Pinus cembra and Larix (Rudner and Sümegi, 2001; Sümegi and Gulyás, 2004), while Betula remains were also recovered shortly after the formation of Lake Balaton between 17,00016,000 cal yr BP (Jakab et al., 2005). 
The reconstructed damp, fen-like habitat had similar characteristics as Nagymohos (NEHungary, Figure 1) (Magyari et al., 1999). Both sites supported boreal brown moss (Pseudocalliergon trifarium and Drepanocladus aduncus) and sedge communities, although Nagymohos was more alike the boreal region of Northern-Europe, where pines with rich herb vegetation dominate on mire surfaces (Eurola et al., 1984). The appearance of Sphagnum species (Sphagnum cf. cuspidata and $S$. palustre) indicated sub-arctic to boreal climate at Nagymohos, where the mean annual temperatures were $>-6--9^{\circ} \mathrm{C}$ with annual precipitation of $>300 \mathrm{~mm}$ (Gignac et al., 2000). These values characterise the northern distribution limit of Sphagnum dominated peatlands in continental North America according to Gignac et al. (2000).

The presence of the floating-leaved macrophyte, Potamogeton natans, furthermore suggests increasing water depth at Kokad; this species frequently occurs in habitats with 2-6 m water-depth (Gaillard, 2007; Hannon and Gaillard, 1997a), but usually tolerates waterdepth down to $1.5 \mathrm{~m}$ (Newman, 2014). Its presence is generally associated with higher water depth (Jakab et al., 2009b), and in still or slowly moving water (Gupta, 2013). We detected its presence since 19,300 cal yr BP. Carex sp. and Eleocharis sp. likely grew in the shallower marginal zone of the lake, likely together with Sparganium minimum, which can tolerate water-depth up to $3 \mathrm{~m}$ (Gaillard, 2007). Potamogeton species require at least $11.7^{\circ} \mathrm{C}$ July mean temperature (Table 5), while Sparganium sp. requires at least $10^{\circ} \mathrm{C}$ (Schenk et al., 2018).

The high concentrations of Daphnia magna/D. pulex ephippia and ostracod shells also support the presence of a calcareous shallow lake at the core location during zones KM-4 and KM-3. Daphnia magna can tolerate high water temperatures up to $25^{\circ} \mathrm{C}$ and low oxygen concentration better, than D. pulex (Wojtal-Frankiewicz, 2012). According to Isarin \& Bohncke (1999), the presence of Ranunculus sect. Batrachium remains suggests mean July 
temperatures $>10^{\circ} \mathrm{C}$, while Typha latifolia is also an important climate indicator in this zone, it requires $>13^{\circ} \mathrm{C}$ July mean temperatures according to Kolstrup (1980) and Gaillard (1984, 2007), while Schenk et al. (2018) suggest at least $15.7^{\circ} \mathrm{C}$. Increasing Typha sp. pollen percentages were already detected from 25,000 cal yr BP at Lake Fehér (Sümegi et al., 2018), and seeds were discovered from 17,470 cal yr BP in Lake Balaton (Jakab et al., 2005).These findings together with the results of climate model simulations $\left(15-17^{\circ} \mathrm{C}\right.$ by Renssen et al. (2001)) support our relatively warm July mean temperature inferences and also warn us that the minimum thermal tolerance requirements of aquatic taxa were already exceeded in the lowland areas during the early LPG period.

The early and continuous presence of Phragmites australis rhizomes in the sediment indicates the development of lakeshore reed-swamp vegetation from $c .18,300$ cal yr $\mathrm{BP}$ or somewhat later if we assume down-core penetration of Phragmites rhizomes and sediment compaction. Phragmites australis together with Hippuris vulgaris became dominant from $\sim 18,000$ cal yr BP until 16,500 cal yr BP. Reed tolerates a wide-range of water-depths, from damp surface up to $2 \mathrm{~m}$ (Gaillard, 2007; Hannon and Gaillard, 1997a), while Hippuris was also part of the first pioneer plant communities in Switzerland, although became dominant rather later, around 15,100 cal $\mathrm{yr} \mathrm{BP}$ when July temperatures increased to more than $13^{\circ} \mathrm{C}$ (Gaillard, 2007; Hannon and Gaillard, 1997a). Its optimum July mean temperatures are higher than $13^{\circ} \mathrm{C}$, while its minimum is $>10^{\circ} \mathrm{C}$ (Gaillard, 1984; Kolstrup, 1980). Nowadays, in the Great Hungarian Plain H. vulgaris prefers shallower streambanks and ponds with fluctuating water-level (usually more than $1 \mathrm{~m}$ deep) and alternating nutrient supply. It occurs together mostly with small, less competitive marsh species (Bölöni and Kun, 2011). For Hippuris the temperature is not a crucial factor, it grows in meso- and eutrophic waters with low species competition (Misson et al., 2016), but it is also found in more alkalitrophic waters (Rybníček and Rybničková, 1968). Hippuris prefers habitats high in $\mathrm{Ca}$, and also enters plant 
communities of Phragmition, Nymphaeion, Ranunculion fluitantis and Littorellion (Rybníček and Rybníčková, 1968). Overall, the plant macrofossil record suggests shallow, alkaline water conditions, similarly to Kołaczek et al. (2015) and a floating brown moss carpet typical of the northern boreal zone between 18,000 and $16,500 \mathrm{cal}$ yr BP.

Our results point to cooling within the Hippuris dominated zone (K-M3) as the timing of the significant decline in Cyperaceae remains both in macrofossil (Figure 4a) and pollen percentages (Appendix C) around 16,200 cal yr BP coincide with the changes of Fe, Mn and $\mathrm{Ca}$ concentrations and the decline in fine sand content and together indicate ecosystem and climate change at Kokad mire. This interval broadly agrees with Heinrich event-1 (HE-1: 17,850-16,200 cal yr BP). Although aquatic remains were scarce in the sediment during this interval, available pollen results suggest arboreal pollen decline (Magyari et al., 1999) and the expansion of Juniperus at mid altitudes in the Carpathians against Pinus sylvestris (Magyari et al., 2014b) that also supports cooler and drier conditions.

Significant changes in the local vegetation occurred at the beginning of zone K-M4a , around 16,500 cal yr BP. The disappearance of Daphnia ephippia and ostracod shells and decreased concentration of U.O.M. and monocotyledon remains suggested that the core location became less vegetated, likely a pelagic habitat without submerged or emergent macrophyte cover, therefore the water-depth probably increased. This inference is also supported by decreasing LOI values at the KM-3/KM-4a boundary (Figure 3), while the decline of $\mathrm{Mn}$ and the increase of $\mathrm{Ca}$ suggest changes in the catchment area. The increase of Fe and $\mathrm{Mn}$ are also followed by an increase of $\mathrm{Ca}$, which probably reflect the development of podzol soil (Fe and Mn leaching), while $\mathrm{Ca}$ likely derived from the chemical weathering of the loess and Ca-rich alluvial sediments. Oxygen availability at the sediment/water interface can be inferred from the concentration changes of $\mathrm{Fe}$ and $\mathrm{Mn}$ (Figure 3), as their redox cycling depends on oxygen availability at the sediment-water interface in lake and mire 
ecosystems (Mackereth, 1965). Podzol soils release $\mathrm{Fe}$ to the lake and precipitaton of $\mathrm{Fe}$ compounds might suggest lower $\mathrm{pH}$ conditions in the lake. The increasing concentrations of Fe and Mn may suggest the development of acidic soils in the catchment and oxidative conditions at the sediment-water interface.

Shortly after this significant change, Ca values began to rise at $365 \mathrm{~cm}(16,170 \mathrm{cal} \mathrm{yr}$ BP) and seeds of aquatic plants disappeared from the record, while $P$. australis vegetative remains were still present, although in decreased concentration until the beginning of the Holocene. Simultaneously with the $\mathrm{Ca}$ increase, $\mathrm{Fe}$ and $\mathrm{Mn}$ concentrations also attained maxima temporarily at 16,170 cal $\mathrm{yr} \mathrm{BP}$, pointing to a substantial change in the lake environment. The grain size decrease implies that erosion from the lakeshore suddenly halted, and oxidative conditions at the sediment-water interface likely prevailed. The organic content of the sediment also increased in this short interval together with increasing concentration of wood and leaf remains. Overall, these features suggest an episodic lake-level decrease followed by a generally lower energy environment in which erosion rates decreased steadily, but the water level likely restored.

According to the geochemical record, the interval between 15,300 cal yr BP and 10,000 cal yr BP was dominated by the precipitation of biogenic carbonate, where the sediment became grey to greenish clayey lime silt. The deposition of biogenic carbonate was initiated in two steps: first around 16,170 cal yr BP, then secondly with a steep increase in Ca values from 15,300 cal yr BP. During the major carbonate formation interval, the lacustrine system was likely characterised by increased water-level. The timing of the biogenic carbonate formation at Kokad mire $(15,200$ cal yr BP) preceded substantially by 3000 years, other similar events identified within the GHP (Cserny and Sümegi, 2003; Jenei et al., 2007; Sümegi et al., 2011, 2013a; Sümegi and Gulyás, 2004; Willis et al., 1995). The high abundance of Chara sp. oogonia together with the increased ostracod remains in the sediment 
indicate a freshly emerging calcium-rich, but nutrient-poor open lake with increased waterdepth. The dominant species, Chara vulgaris prefers alkaline conditions and tolerates well poor nutrient supply (Haas, 1994). These conditions characterised the LG interstadial, with a shift to slightly increased in-lake productivity after 13,600 cal yr BP. The macrofossil assemblages were species-poor in this period and did not display any change during Greenland Stadial 1 (GS-1) that broadly equals with the Younger Dryas cooling between 12,800-11,700 cal yr BP. The scarcity of plant remains at Kokad mire does not allow us to make any inference on the terrestrial vegetation change during the LG period. Regionally gradual expansion of hardwood gallery forests were detected with sporadic occurrence of $P$. sylvestris and Picea around Bátorliget (Sümegi and Juhász, 2004), where Tilia became dominant (Willis et al., 1995). Chironomid-based July mean temperature reconstruction from the South Carpathians revealed an increase in July mean temperatures by $2.8^{\circ} \mathrm{C}$ at 14,700 cal yr BP (Tóth et al., 2012), meanwhile pollen data pointed to $16-17^{\circ} \mathrm{C}$ July mean temperatures in the Romania Carpathians at altitudes $800-900 \mathrm{~m}$ a.s.l. (Feurdean et al., 2008).

The early and mid-Holocene was characterised by the dominance of Phragmites australis at Kokad between 10,000 and 4000 cal yr BP, then Typha species also became frequent. The spread of Typha angustifolia and T. latifolia started at c. 12,200 cal yr BP (during the Younger Dryas period). The maximum concentrations of Chara vulgaris and Tolypella prolifera at $c .4700$ cal yr BP indicated decreasing water-depth at Kokad mire, but still relatively poor nutrient supply, as the latter taxa tolerate water-depth up to maximum $3 \mathrm{~m}$ (Haas, 1994). The shallower water-depth conditions are also supported by the mollusc species Valvata cristata and Planorbis planorbis.

From 4000 cal yr BP, the appearance and high abundance of Sambucus nigra indicates nutrient enrichment and further shallowing of the lake and simultaneously with the increase in sulphur (S) concentration indicates peat formation and the lake-ward expansion of the 
mire/swamp vegetation. The core location turned into reed swamp around 2000 cal yr BP, when the organic content increased to $\sim 80 \%$. Between 3800 and 2000 cal yr BP Cyperus remains were found that suggests seasonal desiccation of the lake/mire shore in this period. The remains of the mollusc fauna consisted of many terrestrial and aquatic habitat species in the upper zones, suggesting periodic water coverage over some areas of the mire. The appearance of Urtica dioica also supported reed swamp spread to the coring location and increasing nutrient availability likely on seasonally dry areas. The further expansion of Phragmites australis and Typha sp. indicate warmer conditions and refer to infilling of the lake basin since 4000 cal yr BP, the increased CHAR values probably imply a higher biomass burning period during the last 4000 years, probably due to human presence in the area.

P. australis, Typha latifolia and T. angustifolia dominated the last 1700 years suggesting continuing reed-swamp vegetation with further increasing organic productivity and accumulation. According to Grace \& Wetzel (1981), T. angustifolia is capable to grow under higher water-depth, and the competition between the two species (T. latifolia and $T$. angustifolia) results in that the latter taxon is restricted to depths less than $80 \mathrm{~cm}$, while the other is present along the entire 2-m long gradient. P. australis and T. angustifolia are both competitive species, $P$. australis grows higher and easily overshadows and out competes $T$. angustifolia under favourable conditions (Jakab et al., 2009). However, P. australis requires coarser sediment, while $T$. angustifolia settles in finer-grained sediment to anchor its roots (Haslam, 1972; Nurminen, 2003; Toivonen and Back, 1989). The presence of all three taxa suggest that the reed swamp had mosaic like surface pattern, with deeper and shallower habitats and varying sediment types that resulted in the presence of all three taxa. Seasonal water-depth fluctuation was likely of large-amplitude similar to the situation today.

In the topmost $54 \mathrm{~cm}$ (last 1700 years) the colonisation of Rumex hydrolapathum occurred, that indicates the terrestrial phase of the mire development. The occurrence of 
Valvata cristata and Segmentina nitida molluscs in high abundance around 1500 cal yr BP also support the transition to mesotrophic conditions (Sümegi et al., 2013). The seeds of $R$. hydrolapathum germinate on waterlogged soils suggesting that the reed swamp was under water during the last 1700 years. The species also requires temperatures above $15^{\circ} \mathrm{C}$ for germination (Van Assche et al., 2002). Urtica dioica and $R$. hydrolapathum are likely reflecting intensified human activity in the area. Sambucus nigra decreased, it was probably restricted to farther habitats from the coring point during this last phase.

The presence of Myriophyllum spicatum in this final phase of the wetland succession point to the presence of shallow open water patches within the reed swamps. The decline in Chara oogonia along with the presence of $M$. spicatum furthermore suggests the development of shallow eutrophic mire conditions. The presence of Galba truncatula also refers to ditches, spring swamps and reeds (Knubben-Schweizer and Torgerson, 2015) in parallel with swampy, humid habitat preferences of Zonitoides nitidus and Carychium minimum (Kurzawska and Kara, 2015). Remains of Eupatorium cannabinum were found frequently together with other tall herbaceous dicotyledonous remains (e.g. Epilobium hirsutum) that usually live in Phragmites australis dominated species-poor habitats (Moore et al., 1984).

\section{Fire history in the Northeastern part of the Great Hungarian Plain}

We found that both biomass-burning rates and fire frequencies were higher during the LPG than during Holocene in the Great Hungarian Plain (Figure 5), when Pinus sp. and Betula species were present around Kokad mire (Figure 4A \& 4B). This finding is at odds with the notion that fire activity was globally lower during the LGM and LPG than during the Holocene due to colder and drier climates, lower than present atmospheric $\mathrm{CO}_{2}$ concentration, 
and lower fuel availability (both woody and herbaceous) (Carcaillet et al., 2009; Harrison \& Prentice, 2003; Lawson et al., 2013; Power et al., 2007). However, there are other records supporting the view that scattered tree populations persisted in East-Central Europe during the last glacial and Lateglacial that burnt regularly even during the LPG (Björkman et al., 2003; Feurdean et al., 2013; Willis et al., 2000, Willis \& Van Andel, 2004; Wohlfarth et al., 2001). For instance, charcoal records from the GHP and the Carpathians indicate high fire activity between 23,000 and 20,000 cal yr BP, 18,000-16,000 cal yr BP (Lake Fehér; Magyari et al. 2014a; Sümegi et al., 2013;) and between 23,000 and 19,500 cal yr BP (Lake St Anne; Magyari et al., 2014b). Moreover, the abundance of microcharcoal particles during the LPG and around 17,500 cal yr BP at Nagymohos also support the intensive fire activity (Magyari et al., 1999).

The reconstructed fire history at Kokad between ca. 15,000 and 4000 cal yr BP differs, however, substantially from other records of the GHP and the Carpathians. At Kokad, biomass-burning rates and fire frequencies were very low during this time interval. Instead, other records indicate that this period was marked by substantial fire-activity changes. For instance, at Lake St Anne higher fire activity was recorded between 15,000 and 8000 cal yr BP (Magyari et al., 2014b), and enhanced fire activity periods during the warm intervals of the Lateglacial (between 14,000 and 12,700 cal yr BP) were associated to the spread of boreal trees in East-Central Europe (Feurdean et al., 2007; Magyari et al., 2012; Willis et al., 1997). In contrast to this, the expansion of hardwood gallery forests including Quercus sp., Ulmus sp., Corylus and Carpinus betulus were detected at Bátorliget with the association of the coniferous Pinus sylvestris (Sümegi \& Gulyás, 2004). According to Tinner et al. (2000), Quercus sp. represent a fire-indifferent class, which is not influenced by fire frequency, the presence of Corylus is favoured by fire while Ulmus sp. is slowly damaged and could be locally extinct by fire. The recorded low fire frequency at Bátorliget could be the sign of 
easily burning conifers than deciduous trees (Johnson, 1995). The lime-rich lateglacial sediments of Kokad contained only plant remains of Phragmites australis, indicating the presence of a reed belt around the mire. This might have contributed to reducing the input of macrocharcoal particles to the mire via secondary dispersal. Around Kokad, the pollen record revealed conifer dominated forest with cold deciduous elements and grassland between 14,000 and 12,700 cal yr BP (Magyari et al., 2019 under revision).

The low early-Holocene biomass-burning rates at Kokad also substantially differ in comparison with other records from Europe (e.g. Carcaillet et al., 2002; Finsinger et al., 2006; Lawson et al., 2013; Power et al., 2007; Rius et al., 2012; Tinner et al., 1998) and from Eastern-Central Europe (Feurdean et al. 2012a; Finsinger et al. 2018, 2014; Feurdean et al., submitted) that indicate high fire frequency during the Early Holocene. Generally, the increasing fire activity in the early Holocene coincides well with the rise of atmospheric $\mathrm{CO}_{2}$ (Harrison and Prentice, 2003) and high summer insolation (Berger and Loutre, 1991). The early Holocene low fire activity at Kokad possibly indicates the low burning potential of the temperate wooded steppe vegetation that developed in the early Holocene around Kokad mire (Magyari et al., 2019 under revision). An alternative, or additional, explanation can be the peculiar location of the site. The Érmellék region is rich in wetlands today (Figure 1). During the early Holocene, this landscape was possibly rich in reed swamps and shallow calcareous lakes and was likely characterised by high groundwater table. These factors might have reduced fire-ignition risk and fire spread.

According to Feurdean et al. (2012) charcoal values in East-Central Europe decreased between 8000 and 5500 cal yr BP. This decline in fire activity is closely connected to strongly declining summer insolation and increasing winter insolation (Berger and Loutre, 1991). Drier conditions were reconstructed in the GHP between 7500 and 6400 cal yr BP (Jakab and Sümegi, 2011) that reflected later at Kokad, around 6500 cal yr BP. Charcoal abundances 
were higher during the early Holocene (c. 9300-7200 cal yr BP) at Bátorliget (Willis et al., 1995). Generally, the early Holocene low biomass-burning periods corresponded to intervals of moister/cooler summers, whereas charcoal peaks were related to warm/dry conditions during the early and mid-Holocene (Feurdean et al., 2012).

The late Holocene burning intensity was relatively weak in comparison with the insolation-driven strong early Holocene burning signal (Feurdean et al., 2012) and fire frequencies were lower than LPG fire frequencies. Higher CHAR abundance starts from 4200 cal yr BP at Kokad, when the water-level likely dropped. Fire events were detected more regularly, which coincides well with the charcoal results of Turbuta (NW Transylvania) (Feurdean et al., 2007). In case of Kokad, we hope that the pollen analyses will help in the near-future to disentangle the natural and man-made fires in this late Holocene interval.

\section{Conclusions}

The lithological, geochemical, plant macrofossil and loss-on-ignition profiles from Kokad-2 core from the Eastern Great Hungarian Plain provided an important record from the last part of the Late Pleniglacial to the present. For reconstructing the local environment, aquatic plants were used as indicators for ecological and temperature conditions together with macrocharcoal particles. Our analyses lead to the following conclusions:

- $\quad$ Around 20,000 cal yr BP a shallow, mesotrophic/eutrophic mire existed at the core location with brown mosses (Pseudocalliergon trifarium, Drepanocladus aduncus), sedges (Carex sp.), Phragmites australis, Typha angustifolia, T. latifolia, Sparganium minimum, Betula nana, Betula pendula/pubescens, Selaginella selaginoides and occasionally Carex sp., Potamogeton natans, Eleocharis sp. were also part of the initial vegetation. 
- Kokad was situated in the periglacial zone with continental climate throughout the LPG involving relatively warm summers even during maximum cooling, the aquatic indicator species with minimum July mean temperature requirements ranging $10-16.1^{\circ} \mathrm{C}$ are within a range that was exceeded relatively early during the LPG and LG warming stages.

- The most warmth-demanding species were Typha angustifolia and Typha latifolia, their presence in the record indicated July mean temperatures $>14-15.7^{\circ} \mathrm{C}$ soon after the LGM.

- $\quad$ From 17,900 cal yr BP, Hippuris vulgaris together with P. australis dominated the local environment as water-level fluctuations occurred, and this vegetation change can likely be connected to the Heinrich-1 cold episode.

- $\quad$ Biogenic carbonate formation started at an early stage, from $c a$. 16,170 cal yr BP and accelerated from 15,200 cal yr BP. Its early onset suggests that warming and chemical weathering intensified in the Eastern Great Hungarian Plain earlier than the Lateglacial warming.

- For the Holocene, warmer and shallower water characterised the mire, strong eutrophication with reed-domination together with increasing macrocharcoal suggest drier conditions for the last 1700 years.

Our study emphasizes the importance of multidisciplinary approach to document changes of local vegetation and its relation to climate in the past. The influence of climate change on lakes and mires is often masked by the changes associated with progressing lakemire succession, affecting their susceptibility for recording climate changes. 


\section{Authors' contribution}

IV, GJ and EKM did the plant macrofossil analyses, IV did the macrocharcoal analyses of Kokad-2 core. Mollusc shells were identified by DT. Figure 1 was constructed by $\mathrm{BT}$ and ZSz. Loss-on-ignition measurement was done by KH. MB and EKM carried out the sediment coring. WF contributed to the macrocharcoal data analyses. ZSZ contributed to the grain-size measurement and data analysis. IV and EKM wrote the manuscript. The project that financed this research is led by EKM. All authors read and approved the final manuscript.

\section{Acknowledgements}

This study was supported by the Hungarian Scientific Fund (OTKA PD 73234 and NF 101362), both held by Enikő K. Magyari and financially supported by GINOP-2.3.2-15-201600019. This study was also supported by a scholarship provided by the French Government (Campus France 2016) awarded to Ildikó Vincze. The work of Gusztáv Jakab was supported by the Higher Education Institutional Excellence Program (1783-3/2018/FEKUTSTRAT) awarded by the Ministry of Human Capacities within the framework of water related researches of Szent István University. The Horiba Partica 950 LA instrument was obtained by KMOP-4.2.1/B-10-2011-0002. We are thankful for the two anonymous reviewers for all the detailed comments. This is MTA-MTM-ELTE Paleo contribution no. 304. 


\section{References}

Aarnes, I., Kühl, N., Birks, H.H., 2012. Quantitative climate reconstruction from late-glacial and early Holocene plant macrofossils in western Norway using the probability density function approach. Rev. Palaeobot. Palynol. 170, 27-39. https://doi.org/10.1016/j.revpalbo.2011.11.001

Alm, T., Birks, H.H., 1991. Late Weichselian flora and vegetation of Andøya, Northern Norway-macrofossil (seed and fruit) evidence from Nedre Æråsvatn. Nord. J. Bot. 11, 465-476. https://doi.org/10.1111/j.17561051.1991.tb01249.x

Atherton, I., 2010. Mosses and liverworts of Britain and Ireland : a field guide. British Bryological Society Plymouth.pp.714; pp. 727.

Backman, A.L., 1948. Najas flexilis in Europa während der Quartärzeit. Soc. pro fauna flora Fenn. 43, 1-45.

Backman, A.L., 1935. Die nördlichsten Fossilfunde von Najas flexilis und Carex pseudocyperus in Finnland. Soc. Sci. Fenn. Comm. Biol. 3, 1-9.

Bengtsson, L., Enell, M., 1986. Chemical analysis, In: Berglund, B.E. (Ed.), Handbook of Holocene Palaeoecology and Palaeohydrology. Wiley, Chichester, pp. 423-451.

Berger, A., Loutre, M.F., 1991. Insolation values for the climate of the last 10 million years. Quat. Sci. Rev. 10, 297-317. https://doi.org/10.1016/0277-3791(91)90033-Q

Binney, H., Edwards, M., Macias-Fauria, M., Lozhkin, A., Anderson, P., Kaplan, J.O., Andreev, A., Bezrukova, E., Blyakharchuk, T., Jankovska, V., Khazina, I., Krivonogov, S., Kremenetski, K., Nield, J., Novenko, E., Ryabogina, N., Solovieva, N., Willis, K., Zernitskaya, V., 2017. Vegetation of Eurasia from the last glacial maximum to present: Key biogeographic patterns. Quat. Sci. Rev. 157, 80-97. https://doi.org/10.1016/j.quas cirev.2016.11.022

Birks, H.J.B., Heiri, O., Seppä, H., Bjune, A.E., 2011. Strengths and weaknes ses of quantitative climate reconstructions based on late-Quaternary biological proxies. Open Ecol. J. 3, 68-110.

Björkman, L., Feurdean, A., Wohlfarth, B., 2003. Late-Glacial and Holocene forest dynamics at Steregoiu in the Gutaiului Mountains, Northwest Romania. Rev. Palaeobot. Palynol. 124, 79-111. https://doi.org/10.1016/S0034-6667(02)00249-X

Blaauw, M., Christen, J.A., 2013. Bacon Manual e V2. 2.

Blott, S.J., Pye, K., 2012. Particle size scales and classification of sediment types based on particle size distributions: Review and recommended procedures. Sedimentology 59, 2071-2096. https://doi.org/10.1111/j.1365-3091.2012.01335.x

Bojnanský, V., Fargašová, A., 2007. Atlas of Seeds and Fruits of Central and East-European Flora: The Carpathian Mountains Region. Springer Science \& Business Media. p. 1078.

Bölöni, J., Kun, A., 2011. Magyarország élőhelyei. Vegetációtípusok leírása és határozója, ÁNÉR. MTA ÖBKI. pp. 441.

Bond, G., Showers, W., Cheseby, M., Lotti, R., Almasi, P., deMenocal, P., Priore, P., Cullen, H., Hajdas, I., Bonani, G., 1997. A Pervasive Millennial-Scale Cycle in North Atlantic Holocene and Glacial Climates. Science (80-. ). 278, 1257-1266. https://doi.org/10.1126/science.278.5341.1257

Borsy, Z., 1989. Az Alföld hordalékkúpjainak negyedidőszaki fejlődéstörténete. Foldr. Ert. XXXVIII., 211224.

Bradák, B., Thamó-Bozsó, E., Kovács, J., Márton, E., Csillag, G., Horváth, E., 2011. Characteristics of Pleistocene climate cycles identified in Cérna Valley loess-paleosolsection (Vértesacsa, Hungary). Quat. Int. 234, 86-97. https://doi.org/10.1016/j.quaint.2010.05.002

Buurman, P., van Lagen, B., Velthorst, E.J., 1996. Manual for Soil and Water Analysis. Department of Soil Science and Geology, Wageningen Agricultural University, p. 314.

Carcaillet, C., Ali, A. a., Blarquez, O., Genries, A., Mourier, B., Bremond, L., 2009. Spatial variability of fire history in subalpine forests: From natural to cultural regimes. Ecoscience 16, 1-12. https://doi.org/10.2980/16-1-3189 
Carcaillet, C., Almquist, H., Asnong,H., Bradshaw, R.H.W., Carrión, J.S., Gaillard, M.-J., Gajewski, K., Haas, J.N., Haberle, S.G., Hadorn, P., Müller, S.D., Richard, P.J.H., Richoz, I., Rösch, M., Sánchez Goñi, M.F., von Stedingk, H., Stevenson, A.C., Talon, B., Tardy, C., Tinner, W., Tryterud, E., Wick, L., Willis, K.J., 2002. Holocene biomass burning and global dynamics of the carbon cycle. Chemosphere 49, 845-863. https://doi.org/10.1016/S0045-6535(02)00385-5

Clark, P.U., Dyke, A.S., Shakun, J.D., Carlson, A.E., Clark, J., Wohlfarth, B., Mitrovica, J.X., Hostetler, S.W., McCabe, A.M., 2009. The Last Glacial Maximum. Science (80-. ). 325.

Cserny, T., Sümegi, P., 2003. Late Quaternary geohistory of Sárrét Basin, based on studies on core Sárrét -2, Hungary. Acta Geol. Hungarica 46, 391-405.

Engel, Z., Nývlt, D., Kř́̌̌zek, M., Treml, V., Jankovská, V., Lisá, L., 2010. Sedimentary evidence of landscape and climate history since the end of MIS 3 in the Krkonoše Mountains, Czech Republic. Quat. Sci. Rev. 29, 913-927. https://doi.org/10.1016/j.quascirev.2009.12.008

Eshel, G., Levy, G.J., Mingelgrin, U., Singer, M.J., 2004. Critical Evaluation of the Use of Laser Diffraction for Particle-Size Distribution Analysis. Soil Sci. Soc. Am. J. 68, 736. https://doi.org/10.2136/sssaj2004.7360

Eurola, S., Hicks, S., Kaakinen, E., 1984a. Key to Finnish Mire Types, in: Moore, P.D. (Ed.), European Mires. Academic Press, London, pp. 11-117. https://doi.org/10.1016/B978-0-12-505580-2.50006-4

Fajer, M., Waga, J.M., Rzetala, M.M.A., Szymczyk, A., Nita, M., Machowski, R., Rzetala, M.M.A., Ruman, M., 2012. The Late Vistulian and Holocene evolution of Jezioro Lake: a record of environmental change in southern Poland found in deposits and landforms. J. Paleolimnol. 48, 651-667. https://doi.org/10.1007/s 10933-012-9634-1

Feurdean, A., Bennike, O., 2004. Late Quaternary palaeoecological and palaeoclimatological reconstruction in the Gutaiului Mountains, northwest Romania. J. Quat. Sci. 19, 809-827. https://doi.org/10.1002/jqs.872

Feurdean, A., 2005. Holocene forest dynamics in northwestern Romania. The Holocene 15, 435-446. https://doi.org/10.1191/0959683605h1803rp

Feurdean, A., Mosbrugger, V., Onac, B.P., Polyak, V., Veres, D., 2007a. Younger Dryas to mid-Holocene environmental history of the lowlands of NW Transylvania, Romania. Quat. Res. 68, 364-378. https://doi.org/10.1016/j.yqres.2007.08.003

Feurdean, A., Wohlfarth, B., Björkman, L., Tantau,I., Bennike, O., Willis, K.J., Farcas, S., Robertsson, A.M., 2007b. The influence of refugial population on Lateglacial and early Holocene vegetationalchang es in Romania. Rev. Palaeobot. Palynol. 145, 305-320. https://doi.org/10.1016/j.revpalbo.2006.12.004

Feurdean, A., Klotz, S., Mosbrugger, V., Wohlfarth, B., 2008. Pollen-based quantitative reconstructions of Holocene climate variability in NW Romania. Palaeogeogr. Palaeoclimatol. Palaeoecol. 260, 494-504. https://doi.org/10.1016/j.palaeo.2007.12.014

Feurdean, A., Spessa, A., Magyari, E.K., Willis, K.J., Veres, D., Hickler, T., 2012a. Trends in biomass burning in the Carpathian region over the last 15,000 years. Quat. Sci. Rev. 45, 111-125. https://doi.org/10.1016/j.quascirev.2012.04.001

Feurdean, A., Liakka, J., Vannière, B., Marinova, E., Hutchinson, S.M., Mosburgger, V., Hickler, T., $2013 a$. 12,000-Years of fire regime drivers in the lowlands of Transylvania (Central-Eastern Europe): a data-model approach. Quat. Sci. Rev. 81, 48-61. https://doi.org/10.1016/j.quascirev.2013.09.014

Feurdean, A., Vanniere, B., Finsinger, W., Warren, D., Connor, S.C., Forrest, M., Liakka, J., Panait, A., Andric, M., Bobek, P., Carter, V.A., Davis, B., Diaconu, A.-C., Dietze, E., Feeser, I., Florescu, G., Galka, M., Giesecke, T., Jahns, S., Jamrichová, E., Kajakalo, K., Kaplan, J.O., Karpinska-Kolaczek, M., Kolaczek, P., Kunes, P., Kupriyanov, D., Lamentowicz, M., Lemmen, C., Magy ari, E.K., Marcisz, K., Marinova, E., Niamir, A., Novenko, E., Obremska, M., Pedziszewska, A., Pfeiffer, M., Poska, A., Rösch, M., Slowinski, M., Stancikaite, M., Szal, M., Swieta-Musznicka, J., Tanțău, I., Theuerkauf, M., Tonkov, S., Valkó, O., Vassiljev, J., Veski, S., Vincze, I., Wacnik, A., Werner, C., Wiethold, J., Hicker, T., n.d. Fire risk modulation by long-term land cover and dominant forest type dynamics in Easter and Central Europe. Biosciences. submitted.

Finsinger, W., Tinner, W., Van Der Knaap, W.O., Ammann, B., 2006. The expansion of hazel (Corylus avellana L.) in the southern Alps: A key for understanding its early Holocene history in Europe? Quat. Sci. 
Rev. 25, 612-631. https://doi.org/10.1016/j.quascirev.2005.05.006

Finsinger, W., Kelly, R., Fevre, J., Magyari, E.K., 2014. A guide to screening charcoal peaks in macrocharcoal-area records for fire-epis ode reconstructions. The Holocene 24, 1002-1008. https://doi.org/10.1177/0959683614534737

Finsinger, W., Fevre, J., Orbán, I., Pál, I., Vincze, I., Hubay, K., Birks, H.H., Braun, M., Tóth, M., Magyari, E.K., 2018. Holocene fire-regime changes near the treeline in the Retezat Mts. (Southern Carpathians, Romania). Quat. Int. 477. https://doi.org/10.1016/j.quaint.2016.04.029

Gábris, G., Nádor, A., 2007. Long-term fluvial archives in Hungary: response of the Danube and Tisza rivers to tectonic movements and climatic changes during the Quaternary: a review and new synthesis. Quat. Sci. Rev. 26, 2758-2782. https://doi.org/http://dx.doi.org/10.1016/j.quas cirev.2007.06.030

Gaillard, M.-J., 1984. Analyse pollinique et macrorestes Végétaux des sediments tardi-et postglaciaires du Grand Marais de Boussens, Moyen-Pays Romand, Suisse. Diss. Bot. 72, 117-136.

Gaillard, M.-J., 2007. Plant Macrofossil Methods and Studies : Paleolimnological applications, in: Encyclopedia of Quaternary Science. Elsevier, pp. 2337-2355.

Gałka, M., Sznel, M., 2013. Late Glacial and Early Holocene development of lakes in northeastern Poland in view of plant macrofossil analyses. Quat. Int., Pan-European Correlations in Quaternary Stratigraphy: SEQS 2011, INQUA Congress, Bern 292, 124-135. https://doi.org/10.1016/j.quaint.2012.11.014

Gałka, M., Tobolski, K., Zawisza, E., Goslar, T., 2014. Postglacial history of vegetation, human activity and lake-level changes at Jezioro Linówek in northeast Poland, based on multi-proxy data. Veg. Hist. Archaeobot. 23, 123-152. https://doi.org/10.1007/s00334-013-0401-7

Genries, A., Finsinger, W., Asnong, H., Bergeron, Y., Carcaillet, C., Garneau, M., Hély, C., A li, A.A., 2012. Local versus regional processes: can soil characteristics overcome climate and fire regimes by modifying vegetation trajectories? J. Quat. Sci. 27, 745-756. https://doi.org/10.1002/jqs.2560

Gignac, L.D., Halsey, L.A., Saint-jean, D.H.V.F., 2000. A bioclimatic model for the distribution of Sphagnum -dominated peatlands in North America under present climatic conditions. J. Biogeogr. 27, $1139-1151$

Gobet, E., Vescovi, E., Tinner, W., 2010. Ein paläoökologischer Beitrag zum besseren Verständnis der natürlichen Vegetation der Schweiz. Bot. Helv. 120, 105-115. https://doi.org/10.1007/s00035-010-0080-2

Grace, J.B., Wetzel, R.G., 1981. Habitat Partitioning and Competitive Displacement in Cattails (Typha): Experimental Field Studies. Am. Nat. 118, 463. https://doi.org/10.1086/283841

Grimm, E., 1992. TILIA and TILIA-GRAPH: Pollen spreadsheet and graphics programs. Aix-en-Provence, p. 52.

Gupta, A.K., 2013. Potamogeton natans. IUCN Red List Threat. Species. https://doi.org/http://dx.doi.org/10.2305/IUCN.UK.2013-1.RLT S.T164479A19495876.en

Haas, J.N., 1994a. First identification key for charophyte oospores from central Europe. Eur. J. Phycol. 29, 227-235. https://doi.org/10.1080/09670269400650681

Hannon, G.E., Gaillard, M.-J.J., 1997. The plant-macrofossil record of past lake-level changes. J. Paleolimnol. 18, 15-28. https://doi.org/10.1023/A:1007958511729

Harris on, S.P., Prentice, C.I., 2003. Climate and CO2 controls on global vegetation distribution at the last glacial maximum: Analysis based on palaeovegetation data, biome modelling and palaeoclimate simulations. Glob. Chang. Biol. 9, 983-1004. https://doi.org/10.1046/j.1365-2486.2003.00640.x

Haslam, S.M., 1972. Phragmites Communis Trin. (Arundo Phragmites L., Phragmites Australis (Cav.) Trin. ex Steudel). J. Ecol. 60, 585-610. https://doi.org/10.2307/2258363

Hedenas, L., 1994. Environments indicated by bryophytes in early Weichselian interstadial deposits from northern Sweden. Lindbergia 19, 87-105.

Heikkilä, M., Fontana, S.L., Seppä, H., 2009. Rapid Lateglacial tree population dynamics and ecosystem changes in the eastern Baltic region. J. Quat. Sci. 24, 802-815. https://doi.org/10.1002/jqs.1254 
Heiri, O., Lotter, A.F., Lemcke, G., 2001. Loss on ignition as a method for estimating organic and carbonate content in sediments: reproducibility and comparability of results. J. Paleolimnol. 25, 101-110. https://doi.org/10.1023/A:1008119611481

Heiri, O., Lotter, A.F., Hausmann, S., Kienast, F., 2003. A chironomid-based Holocene summer air temperature reconstruction from the Swiss Alps. The Holocene 13, 477-484. https://doi.org/10.1191/0959683603hl640ft

Higuera, P.E., Brubaker, L.B., Anderson, P.M., Hu, F.S., Brown, T.A., 2009. Vegetation mediated the impacts of postglacial climate change on fire regimes in the south-centralBrooks Range, Alaska. Ecol. Monogr. 79, 201-219. https://doi.org/10.1890/07-2019.1

Higuera, P.E., Gavin, D.G., Bartlein, P.J., Hallett, D.J., 2010. Peak detection in sediment-charcoal records: impacts of alternative data analysis methods on fire-history interpretations. Int. J. Wildl. Fire 19, 996-1014.

Horiba Inc., 2012. A guidebook to particle size analysis. p. 30.

Huntley, B., Spicer, R.A., Chaloner, W.G., Jarzembowski, E.A., 1993. The Use of Climate Response Surfaces to Reconstruct Palaeoclimate from Quaternary Pollen and Plant Macrofossil Data [and Discussion]. Philos. Trans. R. Soc. London. Ser. B Biol. Sci. 341, 215 LP - 224. https://doi.org/10.1098/rstb.1993.0106

Hupuczi, J., Lócskai, T., Hum, L., Sümegi, P., 2006. Heinrich események kimutatása hazai löszszelvény alapján. Malakológiai Tájékoztató 24, 31-34.

Ifj. Papp, L., Papp, L., Gyarmathy, I., Baranyi, T., 2010. A Kék-Kálló-völgyének természeti értékei. Debrecen. https://doi.org/ISBN: 978-963-08-1030-2

Is arin, R.F.B.B., Bohncke, 1999. Mean July Temperatures during the Younger Dryas in Northwestern and Central Europe as Inferred from Climate Indicator Plant Species. Quat. Res. 51, 158-173. https://doi.org/10.1006/qres.1998.2023

Iversen, J.J.J., 1954. The late-glacial flora of Denmark and its relation to climate and soil. Danmarks Geol. unders $\varnothing$ gelse 2, 87-119.

Jakab, G.G., Sümegi, P., Magyari, E.K., 2004. A new paleobotanical method for the description of Late Quaternary organic sediments (Mire-development pathways and paleoclimatic records from S Hungary). Acta Geol. Hungarica 47, 373-409. https://doi.org/10.1556/AGeol.47.2004.4.4

Jakab, G., Sümegi, P., Szántó, Z., 2005. Késő-glaciális és holocén vízszintingadozások a Szigligeti-öbölben (Balaton) makrofosszília vizsgálatok alapján. (Late glacial and Holocene water level changes in the Szigliget Bay, Lake Balaton based on macrofossil investigations). Földtani Közlöny 135, 405-431.

Jakab, G., Majkut, P., Juhász, I., Gulyás, S., Sümegi, P., Törőcsik, T., 2009. Palaeoclimatic signals and anthropogenic disturbances from the peatbog at Nagybárkány (North Hungary), in: Buczkó, K., Korponai, J., Padisák, J., Starratt, S.W. (Eds.), Developments in Hydrobiology. Springer Netherlands, pp. 87-106.

Jakab, G., Sümegi, P., 2011. Preliminary data on the bog s urface wetness from the Sirok Nyírjes-tó peat bog, Mátra Mts, Hungary. Cent. Eur. Geol. 53, 43-65. https://doi.org/10.1556/CEuGeo 1.53.2010.1.3

Jankovska, V., Pokorný, P., 2008. Forest vegetation of the last full-glacial period in the Western Carpathians (Slovakia and Czech Republic). Preslia 80, 307-324.

Járainé-Komlódi, M., 1969. Adatokaz Alföld negyedkori klíma- és vegetációtörténetéhezII (Quaternary vegetation history of the Great Hungarian Plain). Bot. Közlemények 56, 43-55.

Jenei, M., Gulyás, S., Sümegi, P., Molnár, M., 2007. Holocene lacustrine carbonate formation: Old ideas in the light of new radiocarbon data from a single site in central Hungary. Radiocarbon 49, 1017-1021. https://doi.org/10.1017/S0033822200042879

Johnson,E.A., 1995. Fire and vegetation dynamics Studies from the North American boreal forest. p. 144.

Kaltenrieder, P., Belis, C.A., Hofstetter, S., Ammann, B., Ravazzi, C., Tinner, W., 2009. Environmental and climatic conditions at a potential Glacial refugial site of tree species near the Southern Alpine glaciers. New insights from multiproxy sedimentary studies at Lago della Costa (Euganean Hills, Northeastern Italy). Quat. Sci. Rev. 28, 2647-2662. https://doi.org/10.1016/j.quascirev.2009.05.025 
Kasse, C., Bohncke, S.J.P., Vandenberghe, J., G??bris, G., 2010. Fluvial style changes during the last glacial-interglacial transition in the middle Tisza valley (Hungary). Proc. Geol. Assoc. 121, 180-194. https://doi.org/10.1016/j.pgeola.2010.02.005

Katz, N.J., Katz, S. V., Kipiani, M.G., 1965. Atlas and Keys of Fruits and Seeds Occuring in the Quaternary Deposits of the USSR.

Kelly, R.F., Higuera, P.E., Barrett, C.M., Hu, F.S., 2011. A signal-to-noise index to quantify the potential for peak detection in sediment-charcoal records. Quat. Res. 75, 11-17.

Király, G., Molnár, Z., Bölöni, J., Csiky, J., Vojtkó, A., 2008. Magyaros zág földrajzi kistájainak növényzete (Vegetation of geographical landscapes of Hungary). MTA ÖBKI, Vácrátót.

Kiss, T., Sipos, G., Mauz, B., Mezosi, G., 2012. Holocene aeolian sand mobilization, vegetation his tory and human impact on the stabilized sand dune area of the southern Nyírség, Hungary. Quat. Res. (United States) 78, 492-501. https://doi.org/10.1016/j.yqres.2012.07.002

Kiss, T., Hernesz, P., Sümeghy, B., Györgyövics, K., Sipos, G., 2015. The evolution of the Great Hungarian Plain fluvial system- Fluvial processes in a subsiding area from the beginning of the Weichselian. Quat. Int. 388, 142-155. https://doi.org/10.1016/j.quaint.2014.05.050

Knubben-Schweizer, G., Torgerson, P.R., 2015. Bovine fasciolosis: Control strategies based on the location of Galba truncatula habitats on farms. Vet. Parasitol. 208, 77-83. https://doi.org/http://dx.doi.org/10.1016/j.vetpar.2014.12.019

Kołaczek, P., Gałka, M., Karpińska-Kołaczek, M., Lutyńska, M., 2015. Late Pleniglacial and Late Glacial lake-mire transformations in south-eastern Poland reflected in aquatic and wetland vegetation changes. Quat. Int. https://doi.org/10.1016/j.quaint.2014.04.042

Kolstrup, E., 1980a. Climate and stratigraphy in Northwestern Europe between 30,000 BP and 13,000 BP, with special reference to The Netherlands. Rijks Geologische Dienst.

Kurzawska, A., Kara, M., 2015. The contribution of mollusc shells to the recon struction of environment at the Early Medieval stronghold of Pszczew (Poland). Quat. Int. 390, 126-132. https://doi.org/http://dx.doi.org/10.1016/j.quaint.2015.04.002

Kwiecien, O., Arz, H.W., Lamy, F., Plessen, B., Bahr, A., Haug, G.H., 2009. North Atlantic control on precipitation pattern in the eastern Mediterranean/Black Sea region during the last glacial. Quat. Res. 71, 375-384.

Lawson, I.T., Tzedakis, P.C., Roucoux, K.H., Galanidou, N., 2013. The anthropogenic influence on wildfire regimes: charcoal records from the Holocene and Last Interglacial at Ioannina, Greece. J. Biogeogr. 40, 2324-2334. https://doi.org/10.1111/jbi.12164

Lotter, A.F.A.F., Birks, H.J.B., Hofmann, W., Marchetto, A., 1997. Modern diatom, cladocera, chironomid, and chrysophyte cyst as semblages as quantitative indicators for the reconstruction of past environmental conditions in the Alps. I. Climate. J. Paleolimnol. 18, 395-420. https://doi.org/10.1023/A:1007982008956

Luoto, T.P., Kaukolehto, M., Weckström, J., Korhola, A., Väliranta, M., 2014. New evidence of warm early-Holocene summers in subarctic Finland based on an enhanced regional chironomid-based temperature calibration model. Quat. Res. 81, 50-62. https://doi.org/http://dx.doi.org/10.1016/j.yqres.2013.09.010

Mackereth, F.J.H., 1965. Chemical Investigation of Lake Sediments and their Interpretation. Proc. R. Soc. London. Ser. B, Biol. Sci. 161, 295-309.

Magyari, E., Jakab, G., Rudner, E., Sümegi, P., 1999. Palynological and plant macrofossil data on Late Pleis tocene short-term climatic oscillations in NE-Hungary. Acta Palaeobot. Suppl. 2, 491-502.

Magyari, E., 2002. Climatic versus human modification of the Late Quaternary vegetation in Eastern Hungary. PhD thesis.

Magyari, E.K., Jakab, G., Sümegi, P., Szöőr, G., 2008. Holocene vegetation dynamics in the Bereg Plain, NE Hungary--the Báb-tava pollen and plant macrofossil record. Acta Geogr. Debrecina 42, 1-16.

Magyari, E., Jakab, G., Braun, M., Buczkó, K., textbfBálint, M., 2009. High-resolution study of Late Glacial and Early Holocene vegetation and tree line changes in the Southern Carpathian Mountains. Geophys. Res. 
Abstr. 11, 10549.

Magyari, E.K., Jakab, G., Bálint, M., Kern, Z., Buczkó, K., Braun, M., 2012a. Rapid vegetation response to Lateglacial and early Holocene climatic fluctuation in the South Carpathian Mountains (Romania). Quat. Sci. Rev. 35, 116-130. https://doi.org/10.1016/j.quascirev.2012.01.006

Magyari, E.K., Veres, D., Wennrich, V., Wagner, B., Braun, M., Jakab, G., Karátson, D., Pál, Z., Ferenczy, G., St-Onge, G., Rethemeyer, J., Francois, J.-P., von Reumont, F., Schäbitz, F., 2014a. Vegetation and environmental responses to climate forcing during the Last Glacial Maximum and deglaciation in the East Carpathians: attenuated response to maximum cooling and increased biomass burning. Quat. Sci. Rev., Dating, Synthesis, and Interpretation of Palaeoclimatic Records and Model-data Integration: Advances of the INTIMATE project(INTegration of Ice core, Marine and TErrestrial records, COST Action ES0907) 106, 278-298. https://doi.org/10.1016/j.quascirev.2014.09.015

Magyari, E.K., Kuně̌, P., Jakab, G., Sümegi, P., Pelánková, B., Schäbitz, F., Braun, M., Chytrý, M., 2014 b. Late Pleniglacial vegetation in eastern-central Europe: are there modern analogues in Siberia? Quat. Sci. Rev. 95, 60-79. https://doi.org/10.1016/j.quascirev.2014.04.020

Magyari, E.K., 2015. A Kárpát-medence és DK-Európa késő pleniglaciális és holocén vegetációfejlödése különös tekintettel a gyors felmelegedési és lehülési hullámokra mutatott vegetációs válaszokra Budapest. MTA-MTM-ELTE.

Magyari, E.K., Pál, I., Vincze, I., Veres, D., Korponai, J., Jakab, G., Braun, M., Szalai, Z., Szabó, Z., Allen, J., Finsinger, W., 2019. Warm Younger Dryas summers and early Late Glacial spread of temperate deciduous trees in the Pannonian Basin during the last glacial termination (20-9 kyr cal BP). Quaternary Science Reviews. under revision.

Major, C.O., Goldstein, S.L., Ryan, W.B.F., Lericolais, G., Piotrowski, A.M., Hajdas, I., 2006. The coevolution of Black Sea level and composition through the last deglaciation and its paleoclimatic significance. Quat. Sci. Rev. 25, 2031-2047.

Medzihradszky, Z., Bajzáth, J., 1998. The occurrence of arctic-alpine Betula species in the Hungarian Pleis tocene. Ann. His. Nat. Mus. Nat. Hung. 90, 27-33.

Milecka, K., Kowalewski, G., Szeroczyńska, K., 2011. Climate-related changes during the Late Glacial and early Holocene in northern Poland, as derived from the sediments of Lake Sierzywk. Hydrobiologia 676, 187-202. https://doi.org/10.1007/s 10750-011-0874-2

Misson, G., Macor, A., Boscutti, F., Casolo, V., 2016. Ecological characterisation of hippuris vulgaris populations growing in spring Water Rivers. Phyt. - Ann. Rei Bot. 56, 209-224. https://doi.org/10.12905/0380.phyton56(2)2016-0209

Moore, P. D., Merryfield, D.L., Price, M.D.R., 1984. 6 - The Vegetation and Development of Blanket Mires, in: Moore, Peter D. (Ed.), European Mires. Academic Press, pp. 203-235.

Newman, J., 2014. Centre for Aquatic Plant Management Information Sheet 11 : Potamogeton Information Sheet 11 Pondweed 1-3.

Nurminen, L., 2003. Macrophyte species composition reflecting water quality changes in adjacent water bodies of lake Hiidenvesi, SW Finland. Ann. Bot. Fenn. 40, 199-208.

Ortu, E., Brewer, S., Peyron, O., 2006. Pollen-inferred palaeoclimate reconstructions in mountain areas: Problems and perspectives.J. Quat. Sci. 21, 615-627. https://doi.org/10.1002/jqs.998

Pokorný, P., 2002. A high-resolution record of Late-Glacial and Early-Holocene climatic and environmental change in Czech Republic. Quat. Int. 91, 101-122. https://doi.org/10.1016/S1040-6182(01)00105-7

Pokorný, P., Šída, P., Chvojka, O., Žáčková, P., Kuneš, P., Světlík, I., Veselý, J., 2010. Palaeoenvironmental research of the Schwarzenberg Lake, southern Bohemia, and exploratory excavations of this key Mesolithic archaeological area. Pamatky Archeol. 101, 5-38.

Power, M.J., Marlon, J., Ortiz, N., Bartlein, P.J., Harrison, S.P., Mayle, F.E., Ballouche, A., Bradshaw, R.H.W., Carcaillet, C., Cordova, C., Mooney, S., Moreno, P.I., Prentice, I.C., Thonicke, K., Tinner, W., Whitlock, C., Zhang, Y., Zhao, Y., Ali, A.A., Anderson, R.S., Beer, R., Behling, H., Briles, C., Brown, K.J., Brunelle, A., Bush, M., Camill, P., Chu, G.Q., Clark, J., Colombaroli, D., Connor, S., Daniau, A.-L., 
Daniels, M., Dodson, J., Doughty,E., Edwards, M.E., Finsinger, W., Foster, D., Frechette, J., Gaillard, M.J., Gavin, D.G., Gobet, E., Haberle, S., Hallett, D.J., Higuera, P., Hope, G., Horn, S., Inoue, J., Kaltenrieder, P., Kennedy, L., Kong, Z.C., Larsen, C., Long, C.J., Lynch, J., Lynch, E.A., McGlone, M., Meeks, S., Mensing, S., Meyer, G., Minckley, T., Mohr, J., Nelson, D.M., New, J., Newnham, R., Noti, R., Oswald, W., Pierce, J., Richard, P.J.H., Rowe, C., Goñi, M.F.S., Shuman, B.N., Takahara, H., Toney, J., Turney, C., Urrego-Sanchez, D.H., Umbanhowar, C., Vandergoes, M., Vanniere, B., Vescovi, E., Walsh, M., Wang, X., Williams, N., Wilmshurst, J., Zhang, J.H., 2007. Changes in fire regimes since the Last Glacial Maximum: an assessment based on a global synthes is and analys is of charcoal data. Clim. Dyn. 30, 887-907. https://doi.org/10.1007/s00382-007-0334-x

Rasmussen, S.O., Bigler, M., Blockley, S.P., Blunier, T., Buchardt, S.L., Clausen, H.B., Cvijanovic, I., Dahl-Jensen, D., Johnsen, S.J., Fischer, H., Gkinis, V., Guillevic, M., Hoek, W.Z., Lowe, J.J., Pedro, J.B., Popp, T., Seierstad, I.K., Steffensen, J.P., Svensson, A.M., Vallelonga, P., Vinther, B.M., Walker, M.J.C., Wheatley, J.J., Winstrup, M., 2014. A stratigraphic framework for abrupt climatic changes during the Last Glacial period based on three synchronized Greenland ice-core records: refining and extending the INTIMATE event stratigraphy. Quat. Sci. Rev., Dating, Synthesis, and Interpretation of Palaeoclimatic Records and Model-data Integration: Advances of the INTIMATE project(INTegration of Ice core, Marine and TErrestrial records, COST Action ES0907) 106, 14-28. https://doi.org/10.1016/j.quascirev.2014.09.007

Reimer, P., 2013. IntCal13 and Marine13 Radiocarbon Age Calibration Curves 0-50,000 Years cal BP. Radiocarbon 55, 1869-1887. https://doi.org/10.2458/azu_js_rc.55.16947

Renssen,H., Isarin, R.F.B., Vandenberghe, J., 2001. Rapid climatic warming at the end of the last glacial: New pers pectives. Glob. Planet. Change 30, 155-165. https://doi.org/10.1016/S0921-8181(01)00083-2

Rius, D., Vannière, B., Galop, D., 2012. Holocene history of fire, vegetation and land use from the central Pyrenees (France). Quat. Res. 77, 54-64. https://doi.org/10.1016/j.yqres.2011.09.009

Rudner, Z.E., Sümegi, P., 2001a. Recurring Taiga forest-steppe habitats in the Carpathian Basin in the Upper Weichselian. Quat. Int. 76, 177-189.

Rybníček, K., Rybníčková, E., 1968a. The History of Flora and Vegetation on the Bláto mire in Southeastern Bohemia, Czechoslovakia (Palaeoecological Study). Folia Geobot. Phytotaxon. 3, 117-142. https://doi.org/10.2307/4179487

Samuelsson, G., 1934. Die Verbreitung Der H'oheren Wasserpflanzen In Nordeuropa. Acta Phyt Suec VI, $1-211$.

Sanchi, L., Ménot, G., Bard, E., 2014. Insights into continental temperatures in the northwestern Black Sea area during the Last Glacial period using branched tetraether lipids. Quat. Sci. Rev. 84, 98-108.

Schenk, F., Väliranta, M., Muschitiello, F., Tarasov, L., Heikkilä, M., Björck, S., Brandefelt, J., Johansson, A. V., Näslund, J.O., Wohlfarth, B., 2018. Warm summers during the Younger Dryas cold reversal. Nat. Commun. 9. https://doi.org/10.1038/s41467-018-04071-5

Schermann, S., 1967. Magismeret I-II (Seed identification, Volume I-II; in Hungarian). Akadémiai Kiadó, Budapest.

Seppä, H., Birks, H.J.B., Odland, A., Poska, A., Veski, S., 2004. A modern pollen-climate calibration set from northern Europe: developing and testing a tool for palaeoclimatological reconstructions. J. Biogeogr. $31,251-267$.

Smith, A.J.E., 2004. The moss flora of Britain and Ireland. Cambridge University Press. p. 1012.

Stuiver, M., Reimer, J., 1993. Extended 14C database and revised CALIB 3.014 C age calibration program. Radiocarbon 35, 215-230.

Sümegi, P., Krolopp, E., 1995. A magyarországi würm korú löszök képződésének paleoökológiai rekonstrukciója (Paleoecological reconstruction of Würmian loesses based on Mollusca fauna). Földtani Közlöny 124, 125-148.

Sümegi, P., Krolopp, E., Hertelendi, E., 1998. A Ságvár-Lascaux interstadiális paleoökológiai rekonstrukciója. Acta Geogr. ac Geol. Meteorol. Debrecina 34, 165-180.

Sümegi, P., Krolopp, E., 2002. Quatermalacological analyses for modeling of the Upper Weichselian 
palaeoenvironmental changes in the Carpathian Basin. Quat. Int., Late Pleistocene and Holocene Investigations in Europe. Internati onal Conference on Past Global Changes (PAGES) 91, 53-63. https://doi.org/10.1016/S1040-6182(01)00102-1

Sümegi, P., Gulyás, S., 2004a. The geohistory of Bátorliget marshland: an example for the reconstruction of late quaternary environmental changes and past human impact from the northeastern part of the Carpathian Basin, Archaeolingua: Main series. Archaeolingua.

Sümegi, P., Juhász, I., 2004b. Analysis of early vegetation history of Bátorliget marshland, in: Sümegi, P., Gulyás, S. (Eds.), The Geohistory of Bátorliget Marshland. Archaeolingua, Budapest, pp. 155-159.

Sümegi, P., 2005. Loess and Upper Paleolithic Environment in Hungary: An Introduction to the Environmental History of Hungary. Aurea.

Sümegi, P., Molnar, M., Jakab, G., Persaits, G., Majkut, P., Pall, D.G., Gulyas, S., Jull, A.T., Törőcsik, T., 2011. Radiocarbon-Dated Paleoenvironmental Changes on a Lake and Peat Sediment Sequence from the Central Great Hungarian Plain (Central Europe) During the Last 25,000 Years. Radiocarbon 53, 85-97. https://doi.org/10.2458/azu_js_rc.53.3444

Sümegi, P., Magyari, E., Dániel, P., Molnár, M., Törőcsik, T., 2013. Responses ofterrestrial ecosystems to Dans gaard-Oeshger cycles and Heinrich-events: A 28,000-year record of environmental changes from SE Hungary. Quat. Int. 293, 34-50.

Sümegi, P., Molnár, D., Gulyás, S., Náfrádi, K., Sümegi, B.P., Törőcsik, T., Persaits, G., Molnár, M., Vandenberghe, J., Zhou,L., 2018. High-resolution proxy record of the environmental response to climatic variations during transition MIS3/MIS2 and MIS2 in Central Europe: The loess -paleosolsequence of Katymár brickyard (Hungary). Quat. Int. https://doi.org/10.1016/j.quaint.2018.03.030

Szafer, W., 1954. Plioceńska flora okolic Czorsztyna i jej stosunek do plejstocenu... Pliocene flora from the vicinity of Czors ztyn (West Carpathians) and its relations ship to the pleistocene... Pr. Inst. Geol. 11, 1-238.

Szafer, W., n.d. Flora plioceńska z Krościenka n/Dunajcem (The Pliocene flora of Kroscienko in Poland Summary., Rozpr. Wydz. Mat.-Przyr. PAU. Polska Akademija Umiejȩtności.

Tantau, I., Reille, M., de Beaulieu, J.-L., Farcas, S., 2006. Late Glacial and Holocene vegetation history in the southern part of Transylvania (Romania): pollen analysis of two sequences from Avrig. J. Quat. Sci. 21, 49-61. https://doi.org/10.1002/jqs.937

Timár, G., Sümegi, P., Horváth, F., 2005. Late Quaternary dynamics of the Tis za River: evidence of climatic and tectonic controls. Tectonophysics 410, 97-110. https://doi.org/10.1016/j.tecto.2005.06.010

Tinner, W., Conedera, M., Ammann, B., Gaggeler, H.W.H.W.W., Gedye, S., Jones, R., Sagesser, B., Conedera, M., Gaggeler, H.W.H.W.W., Sagesser, B., Gedye, S., Jones, R., 1998. Pollen and charcoal in lake sediments compared with historically documented forest fires in southern Switzerland since AD 1920. The Holocene 8, 31-42. https://doi.org/10.1191/095968398667205430

Tinner, W., Conedera, M., Gobet, E., Hubschmid, P., Wehrli, M., Ammann, B., 2000. A palaeoecological attempt to classify fire sensitivity of trees in the southern Alps 5, 565-574.

Tinner, W., Hubschmid, P., Wehrli, M., Ammann, B., Conedera, M., 1999. Long-term forest fire ecology and dynamics in southern Switzerland. J. Ecol. 87, 273-289. https://doi.org/10.1046/j.1365-

2745.1999.00346.x

Toivonen, H., Back, S., 1989. Changes in aquatic vegetation of a small eutrophicated and lowered lake (southern Finland). Ann. Bot. Fenn. 26, 27-38.

Tomlinson, P., 1985. Bud-scale identification guide. Circaea 3, 41-132.

Tonkov, S., Possnert, G., Bozilova, E., 2011. The Lateglacial in the Rila Mountains (Bulgaria) revisited: The pollen record of Lake Ribno (2184m). Rev. Palaeobot. Palynol. 166, 1-11. https://doi.org/10.1016/j.revpalbo.2011.04.004

Tóth, M., Heiri, O., Ildikó, V., Mihály, B., Magyari, E.K., n.d. Chironomid-inferred summer air temperature and limnological changes during the Lateglacial and early Holocene in the East Carpathias.

Tóth, M., Magyari, E.K., Brooks, S.J., Braun, M., Buczkó, K., Bálint, M., Heiri, O., 2012a. A chironomid - 
based reconstruction of late glacial summer temperatures in the southern Carpathians (Romania). Quat. Res. 77, 122-131. https://doi.org/10.1016/j.yqres.2011.09.005

Tóth, M., Magyari, E.K., Buczkó, K., Braun, M., Panagiotopoulos, K., Heiri, O., 2015. Chironomid -inferred Holocene temperature changes in the South Carpathians (Romania). The Holocene 25, 569-582. https://doi.org/10.1177/0959683614565953

Troels-Smith, J., 1955. Karakterisering af lose jordarter. Characterization of unconsolidated sediments. Danmarks Geol. Undersogelse 4, 1-73.

Tzedakis, P.C., Emerson, B.C., Hewitt, G.M., 2013. Cryptic or mystic? Glacial tree refugia in northern Europe. Trends Ecol. Evol. 28, 696-704. https://doi.org/10.1016/j.tree.2013.09.001

Väliranta, M., Kultti, S., Seppä, H., 2006. Vegetation dynamics during the Younger Dryas -Holocene transition in the extreme northern taiga zone, northeastern European Russia. Boreas 35, 202-212. https://doi.org/10.1111/j.1502-3885.2006.tb01150.x

Väliranta, M., Salonen, J.S., Heikkilä, M., Amon, L., Helmens, K., Klimaschewski, A., Kuhry, P., Kultti, S., Poska, A., Shala, S., Veski, S., Birks, H.H., 2015. Plant macrofossil evidence for an early onset of the Holocene summer thermal maximum in northernmost Europe. Nat. Commun. 6, 6809. https://doi.org/10.1038/ncomms 7809

Van Assche, J., Van Nerum, D., Darius, P., 2002. The comparative germination ecology of nine Rumex species. Plant Ecol. 159, 131-142. https://doi.org/10.1023/A:1015553905110

Velichkevich, F.Y., Zastawniak, E., 2008. Atlas of Vascular Plant Macroremains from the Pleistocene of Central and Eastern Europe, Part II-Herbaceous Dicotyledons. W. Szafer Inst. Bot. Polish Acad. Sci. Cracow 1-379.

Walker, M., Johnsen, S., Rasmussen, S.O., Popp, T., Steffensen, J.-P., Gibbard, P., Hoek, W., Lowe, J., Andrews, J., Björck, S., Cwynar, L.C., Hughen, K., Kershaw, P., Kromer, B., Litt, T., Lowe, D.J., Nakagawa, T., Newnham, R., Schwander, J., 2009. Formal definition and dating of the GSSP (Global Stratotype Section and Point) for the base of the Holocene using the Greenland NGRIP ice core, and selected auxiliary records. J. Quat. Sci. 24, 3-17. https://doi.org/10.1002/jqs.1227

Whitmore, J., Gajewski, K., Sawada, M., Williams, J.W., Shuman, B., Bartlein, P.J., Minckley, T., Viau, A.E., III, T.W., Shafer, S., Anderson,P., Brubaker, L., 2005. Modern pollen data from North America and Greenland for multi-scale paleoenvironmental applications. Quat. Sci. Rev. 24, 1828-1848. https://doi.org/http://dx.doi.org/10.1016/j.quascirev.2005.03.005

Wick, L., Tinner, W., 1997. Vegetation changes and timberline fluctuations in the central Alps as indicators of Holocene climatic oscillations. Arct. Alp. Res. 29, 445-458. https://doi.org/10.2307/1551992

Willis, K.J., Braun, M., Sümegi, P., Tóth, A., 1997. Does soil change cause vegetation change or vice versa? A temporal pers pective from Hungary. Ecology 78, 740-750.

Willis, K.J., Rudner, E., Sümegi, P., 2000. The full-glacial forests of central and southeastern Europe. Quat. Res. 53, 203-213.

Willis, K J, Sumegi, P., Braun, M., Toth, A., 1995. The Late Quaternary Environmental History of Batorliget, Ne Hungary. Palaeogeogr. Palaeoclimatol. Palaeoecol. 118, 25-47.

https://doi.org/doi:10.1016/0031-0182(95)00004-6

Willis, K.J., van Andel, T.H., 2004. Trees or no trees? The environments of central and eastern Europe during the Last Glaciation. Quat. Sci. Rev. 23, 2369-2387. https://doi.org/10.1016/j.quascirev.2004.06.002

Wohlfarth, B., Hannon, G., Feurdean, A., Ghergari, L., Onac, B.P., Possnert, G., 2001. Reconstruction of climatic and environmental changes in NW Romania during the early part of the last deglaciation (??? 15,000-13,600 cal yr BP). Quat. Sci. Rev. 20, 1897-1914. https://doi.org/10.1016/S0277-3791(01)00014-2

Wohlfarth, B., Tarasov, P., Bennike, O., Lacourse, T., Subetto, D., Torssander,P., Romanenko, F., 2006. Late Glacial and Holocene Palaeoenvironmental Changes in the Rostov-Yaroslavl' Area, West Central Russia. J. Paleolimnol. 35, 543-569. https://doi.org/10.1007/s 10933-005-3240-4

Wojtal-Frankiewicz, A., 2012. The effects of global warming on Daphnia spp. population dynamics: A review. Aquat. Ecol. 46, 37-53. https://doi.org/10.1007/s 10452-011-9380-x 


\section{Figure legend}

Table 1 Lithostratigraphic description of Kokad-2 (Kokad, Hungary) sediment sequence. The description follows the Troels-Smith sediment description scheme (Troels-Smith, 1955b).

\begin{tabular}{llll}
\hline Depths (cm) & Troels-Smith symbols & Description & Units \\
\hline $0-72$ & Th2Ld1As1Ga+ & $\begin{array}{l}\text { brownish black reed dominated peat with frequent mollusc } \\
\text { shells }\end{array}$ & 7 \\
\hline $72-213$ & As2Ag1Ld1Ga+Th+ & $\begin{array}{l}\text { mid-grey- grey organic rich claysilt with plant macrofossils } \\
\text { (rhizomes) }\end{array}$ & 6 \\
\hline $213-300$ & Lc2As2 & lightgrey - mid-grey, greenish clayey lime with mollusc shells & 5 \\
\hline $300-400$ & Ld1As2Ag1G+ & $\begin{array}{l}\text { mid-brown - brown or occasionnallyyellowish clayey sand } \\
\text { with carbonate precipitation between 362-367 cm }\end{array}$ & 4 \\
\hline $400-595$ & As1Ag2Ga1Ld+Dg+ & $\begin{array}{l}\text { dark-brown - mid-brown siltyclay with black charcoal layer } \\
\text { intercalations }\end{array}$ & 3 \\
\hline $595-600$ & Ga2As1Ag1 & lightgrey fine clayey sand & 2 \\
\hline $600-635$ & Ag2As1Ga1Dg+ & mid-grey- light-grey claysilt with black charcoal layers & 1 \\
\hline
\end{tabular}




\section{Journal Pre-proof}

Table 2 Results of the AMS ${ }^{14}$ C measurements of Kokad-2 core, Kokad, Hungary.

\begin{tabular}{|c|c|c|c|c|c|}
\hline Laboratory & Dated material & Depth $(\mathrm{cm})$ & $\begin{array}{l}\text { 14C ages } \\
\text { BP }\end{array}$ & $\begin{array}{l}\text { Calibrated BP age ranges } \\
(26)\end{array}$ & Remarks \\
\hline Poznań & Phragmites australis stems & $3-4$ & $107,47 \pm 0,4$ & & $\begin{array}{l}\text { modern, } 0.74 \\
\mathrm{mgC}\end{array}$ \\
\hline Poznań & Sambucus nigra seed, indet seed and macrocharcoal & 58 & $1870 \pm 30$ & 1724-1877 & \\
\hline Poznań & Sambucus nigra seeds, macrocharcoal and wood fragments & 71 & $2250 \pm 30$ & $2156-2267$ & \\
\hline Poznań & Phragmites australis stems & $76-78$ & $920 \pm 40$ & $758-924$ & outlier, $0.1 \mathrm{mgC}$ \\
\hline Poznań & Charcoal & $104-107$ & $3444 \pm 33$ & $3631-3783$ & \\
\hline Poznań & Charcoal & $115-119$ & $3100 \pm 33$ & $3226-3383$ & \\
\hline Poznań & Phragmites australis stems & $121-123$ & $915 \pm 30$ & $762-920$ & outlier, $0.74 \mathrm{mgC}$ \\
\hline Debrecen & $<180 \mu \mathrm{m}$ fine organic matter, plant macrofossils & 179 & $7506 \pm 45$ & $8277-8398$ & \\
\hline Poznań & Charcoal & $195-198$ & $6699 \pm 51$ & $7481-7660$ & outlier \\
\hline Debrecen & Biogenic carbonate & 239 & $11412 \pm 46$ & $13133-13361$ & \\
\hline Debrecen & Biogenic carbonate & 239 & $11823 \pm 46$ & $13547-13762$ & \\
\hline Poznań & Cyperaceae leaves and stems & $242-244$ & $1530 \pm 50$ & $1326-1532$ & outlier, $0.1 \mathrm{mgC}$ \\
\hline Debrecen & Schoenoplectussp. and Carexsp. leaves & 279 & $1357 \pm 37$ & $1236-1337$ & outlier \\
\hline Debrecen & Biogenic carbonate & 279 & $12825 \pm 50$ & $15117-15525$ & \\
\hline Debrecen & Biogenic carbonate & 279 & $12920 \pm 49$ & $15233-15661$ & \\
\hline Debrecen & $<180 \mu \mathrm{m}$ fine organic matter, plant macrofossils & 326 & $14715 \pm 59$ & $17704-18084$ & outlier \\
\hline Poznań & Sedge leaf fragments and charcoal & $392-394$ & $25330 \pm 140$ & $28983-29780$ & outlier \\
\hline Debrecen & Moss and Carex sp. leaves & 422 & $13582 \pm 62$ & $16154-16619$ & \\
\hline Debrecen & Charcoal & 465 & $14419 \pm 56$ & $17370-17805$ & \\
\hline Poznań & Carexsp. and moss leaves, Betula nana fruit, plant macrofossils & $498-500$ & $10930 \pm 50$ & $12703-12929$ & outlier \\
\hline Debrecen & Moss and Carex sp. leaves, indet seeds & 553 & $14326 \pm 63$ & $17212-17655$ & \\
\hline Debrecen & Moss and Carex sp. leaves, indet seeds & $598-600$ & $14635 \pm 63$ & $17621-18001$ & outlier \\
\hline Poznań & Wood branchlet & $599-601$ & $16280 \pm 90$ & 19416-19954 & $0.72 \mathrm{mgC}$ \\
\hline
\end{tabular}


Table 3 Plant macrofossil assemblage zones of Kokad-2 core

\begin{tabular}{|c|c|c|c|c|}
\hline \multicolumn{5}{|c|}{ Macrofossil assemblage zones } \\
\hline Zone & $\begin{array}{c}\text { Depth }(\mathrm{cm}) \\
\text { Age (cal yr BP) }\end{array}$ & Characteristics of zone & Inferred local vegetation & $\begin{array}{l}\text { Inferred temperatures of lake } \\
\text { macrophytes }\end{array}$ \\
\hline K-M1 & $620-605$ & $\begin{array}{l}\text { High concentration of bryophyte remains (mainly } \\
\text { Pseudocalliergon trifarium and Drepanocladus } \\
\text { aduncus), wood fragments and macrocharcoal, } \\
\text { coleoptera and Daphniasp. ephippium, } \\
\text { Early presence of Phragmites australis and Typha } \\
\text { sp. species, Selaginella selaginoides megaspores } \\
\text { are abundant, occurence of Carex sp., Sparganium } \\
\text { minimum, cf. Juncus, Eleocharis sp. seeds }\end{array}$ & $\begin{array}{l}\text { Damp, poorly vegetated fen- } \\
\text { like habitat, neutral or alkaline }\end{array}$ & $\begin{array}{l}\text { Remains of Typha angustifolia imply } \\
\text { to at least } 10^{\circ} \mathrm{C} \text { minimum } \\
\text { temperature, while } T \text {. latifolia refers } \\
\text { to a minimum temperature of } 15.7^{\circ} \mathrm{C}\end{array}$ \\
\hline K-M2 & $\begin{array}{l}605-498 \\
19,700-17,900\end{array}$ & $\begin{array}{l}\text { Increased concentrations of Daphnia sp.species, } \\
\text { monocotyledon remains and U.O.M., wood } \\
\text { fragments are abundant, increased abundance of } \\
\text { Phragmites australis, occurence of Chara vulgaris } \\
\text { oogonium and mollusc shells } \\
\text { Occurence of Betula sp. seeds and Selaginella } \\
\text { selaginoides megaspores still abundant }\end{array}$ & 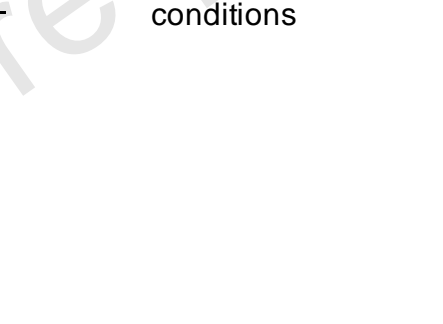 & $\begin{array}{c}\text {; species like Sparganium minimum, } \\
\text { Juncus sp. and Eleocharis sp. } \\
\text { suggest low lake-level conditions. }\end{array}$ \\
\hline K-M3 & $498-400$ & $\begin{array}{l}\text { Increased concentrations of Phragmites australis, } \\
\text { ostracod shells, decreased abudance of wood } \\
\text { fragments, monocotyledon remains and coleoptera } \\
\text { Dominated by Hippuris vulgaris seeds, also high } \\
\text { concentration of Betula-type seeds (both Betula } \\
\text { nana and Betula pendula/pubenscens), occurence } \\
\text { of Carex cf. acutiformis seeds }\end{array}$ & $\begin{array}{l}\text { Reed-swamp vegetation with } \\
\text { mare's tail and few tree } \\
\text { individuals nearby the mire }\end{array}$ & $\begin{array}{c}\text { The minimum mean July } \\
\text { temperature of Hippuris vulgaris is } \\
\text { higher than } 10^{\circ} \mathrm{C} \text {, while its optimum } \\
\text { is higher than } 13^{\circ} \mathrm{C} \text {. }\end{array}$ \\
\hline K-M4a & $\begin{array}{l}400-316 \\
16,950-1,5600\end{array}$ & $\begin{array}{l}\text { Decreased concentration of Phragmites australis, } \\
\text { disappearance of coleoptera and Daphnia sp. } \\
\text { remains } \\
\text { Last appearance of Hippuris vulgaris seeds at the } \\
\text { beginning of the zone, no other seeds were found }\end{array}$ & $\begin{array}{l}\text { Poorly vegetated habitat with } \\
\text { increasing water-level }\end{array}$ & - \\
\hline
\end{tabular}


K-M4b

$316-210$

$15,600-10,500$
Low abundance of Phragmites australis, re-

appearance of ostracod shells, Chara vulgaris

presence

No seeds were detected
Poorly vegetated habitat with

probably shallower water-

level conditions
K-M5

$210-120$

$10,500-3950$

K-M6

$\begin{array}{ll} & \text { Increased concentration of macrocharcoal and } \\ & \text { Typha sp. rhizomes, Phragmites australis } \\ & \text { dominance and re-appearance of Daphnia sp. } \\ & \text { ephippium }\end{array}$

$120-54$

Dominated by Typha angustifolia and Sambucus

nigra seeds, Typha latifolia abundance, appearance

$3950-1700$

K-M7 of Urtica dioica remains ephippium

Increased concentration of Phragmites australis,

.

prolifera oogonium, Typha sp. remains frequent

Appearance of Eupatorium cannabium seeds at the

Reed-swamp vegetation with Remains of Typhasp. imply to warm, shallower water-level conditions

at least $15.7^{\circ} \mathrm{C}$ minimum temperature

\section{Shallower water-level}

conditions with reed

domination and bulrush,

anoxic conditions and

occassional desiccation

The minimum mean July temperature of Typha latifolia imply to warmer than $15.7^{\circ} \mathrm{C}$ conditions
High concentration of Phragmites australis and

Typha sp., increased concentration of

macrocharcoal and U.O.M

Typha angustifolia and Typha latifolia dominance, decreased abundance of Sambucus nigra,

appearance of Rumex hydrolapathum and

Myriophyllum spicatum remains
Reed-swamp with bulrush and shallow water-level conditions
The minimum mean July temperature of Typha latifolia imply to warmer than $15.7^{\circ} \mathrm{C}$ conditions which is supported by the presence of Myriophyllum spicatum $\left(>12^{\circ} \mathrm{C}\right.$ minimum temperature) 
Table 4 Mollusc shell remains of the Kokad-2 core, identified by Tamás Deli. A: Paleoecological group: A1: Rheophylous species, A2: Ditch species, A3: Slum species, A4: Hygrophylous species, A5: Mesophylous and xerophylous species. B: Paleoclimatological group: B1: Intermediate species, B2: Cold-resistant species, B3: Thermophilous species. C: Biogeographic group: C1: Holarctic species, C2: Palearctic species, C3: Eurosiberian species, C4: Eastern European species, C5: Central and SEE European species.

\begin{tabular}{|c|c|c|c|c|}
\hline Species list & $\begin{array}{l}\text { Habitat } \\
\text { prefrences }\end{array}$ & A & B & $\mathrm{C}$ \\
\hline Valvata cristata & aquatic & $\mathrm{A} 2$ & B1 & $\mathrm{C} 2$ \\
\hline Galba truncatula & aquatic & $\mathrm{A} 2$ & B1 & $\mathrm{C} 1$ \\
\hline Planorbis planorbis & aquatic & $\mathrm{A} 2$ & B1 & $\mathrm{C} 2$ \\
\hline Anisus septemgyratus & aquatic & $\mathrm{A} 2$ & B1 & C4 \\
\hline Gyraulus laevis & aquatic & $\mathrm{A} 2$ & $\mathrm{~B} 1$ & $\mathrm{C} 1$ \\
\hline Gyraulus crista & aquatic & $\mathrm{A} 2$ & $\mathrm{~B} 1$ & C1 \\
\hline Segmentina nitida & aquatic & $\mathrm{A} 2$ & B1 & $\mathrm{C} 2$ \\
\hline Carychium minimum & terrestrial & A4 & $\mathrm{B} 1$ & C3 \\
\hline Succinella oblonga & terrestrial & A4 & $\mathrm{B} 2$ & C3 \\
\hline Oxyloma elegans & terrestrial & A4 & $\mathrm{B} 2$ & C3 \\
\hline Vallonia enniensis & terrestrial & A4 & B3 & C5 \\
\hline Vallonia pulchella & terrestrial & A5 & B1 & C1 \\
\hline Zonitoides nitidus & terrestrial & A4 & B1 & $\mathrm{C} 1$ \\
\hline Pseudotrichia rubiginosa & terrestrial & A4 & B1 & C3 \\
\hline
\end{tabular}

A: Paleoecological group; B: Paleoclimatological group; C: Biogeographic group 
Table 5 Minimum and optimum mean July temperatures of selected macrophytes at Kokad mire. For the reconstruction, previously published temperatures of Kolstrup (1980), Gaillard (1964) and Schenk et al. (2018) were used. Taxa marked by a star follow the mean July temperature data of Schenk et al. (2018).

\begin{tabular}{|c|c|c|}
\hline \multicolumn{3}{|c|}{ Minimum and optimum mean July temperatures of selected macrophytes } \\
\hline & Minimum July $\left({ }^{\circ} \mathbf{C}\right)$ & Optimum July $\left({ }^{\circ} \mathrm{C}\right)$ \\
\hline Hippuris vulgaris & $>10$ & $>13$ \\
\hline Myriophyllum spicatum & 10 & $>10$ \\
\hline Myriophyllum spicatum* * & $12.1-12.2$ & - \\
\hline Myriophyllum verticillatum & $>10$ & $>13$ \\
\hline Myriophyllum verticillatum ${ }^{*}$ & $13.8-13.9$ & - \\
\hline Typha sp.* & 15.7 & - \\
\hline Typha latifolia & $12-13$ & 15 \\
\hline Typha latifolia-type * & 15.7 & - \\
\hline Typha angustifolia & $>14$ & - \\
\hline Potamogetonsp.* & 11.7 & - \\
\hline Littorellasp. * & 16.1 & - \\
\hline Betulasp.* & 10 & - \\
\hline
\end{tabular}




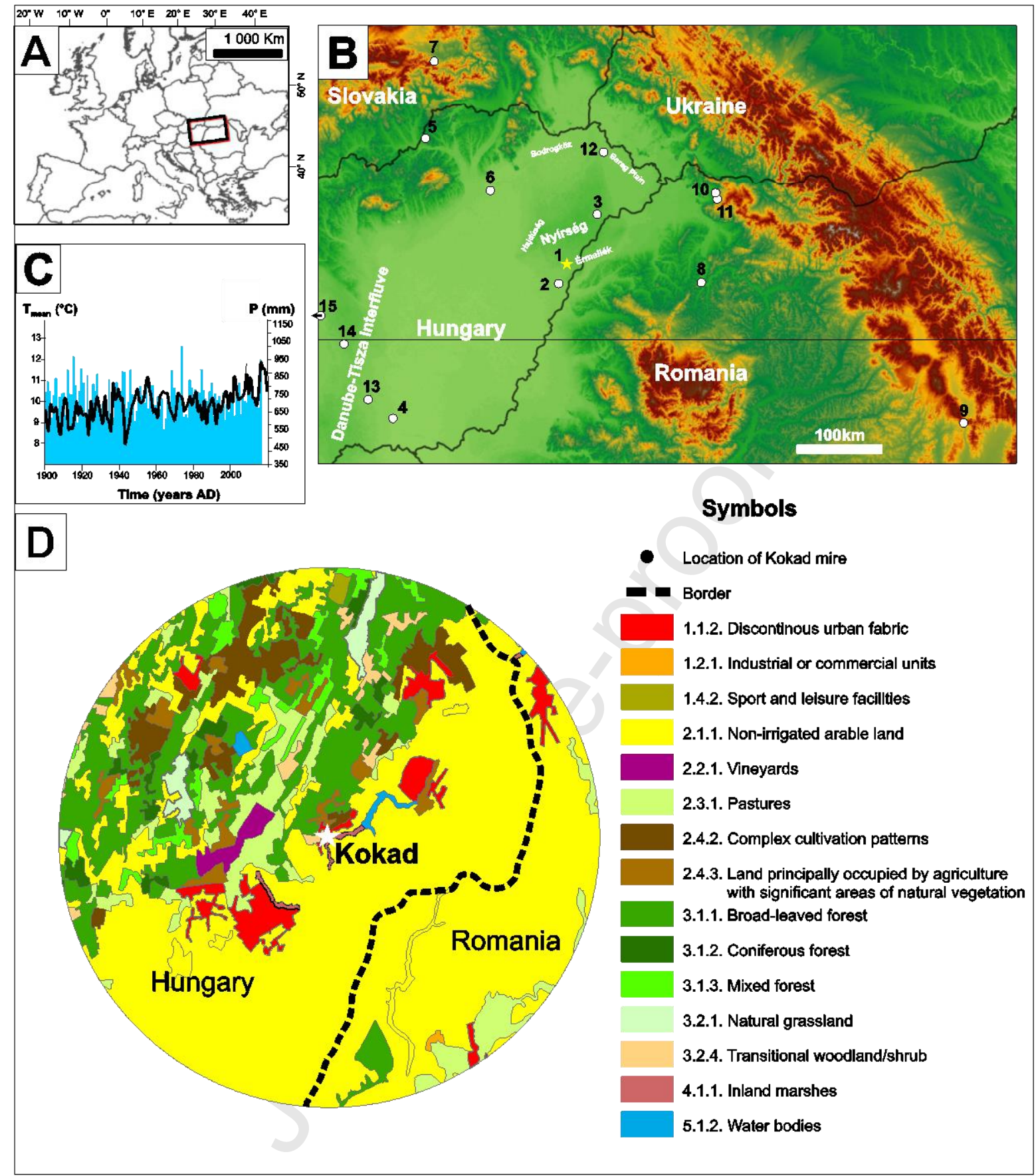

\section{Figure 1}

A: Map showing the location of the study area in Europe. B: Topographical map of the Carpathian Basin indicating the location of palaeorecords mentioned in the text: (1) Kokad (Csinády 1960), (2) Pocsaj (Félegyházi 1995), (3) Bátorliget (Willis et al. 1995), (4) Lake Fehér (Sümegi et al. 1999; 2013), (5) Nagy mohos, Kelemér (Magy ari et al. 1999, 2014) (6) Sarló-hát (Magyari 2015), (7) Safarka, Slovakia (Jankowska et al. 2002), (8) Turbuta, Romania (Feurdean et al., 2007), (9) Lake St Anne, Romania (Magyari et al. 2014), (10) Preluca Tiganului, Romania (Björkmann et al. 2002), (11) Steregoiu, Romania (Björkmann et al. 2002), (12) Aranyosapáti (Borsy et al. 1982), (13) Csólyospálos (Jenei 2005; Sümegi et al. 2015), (14) Lake Kolon (Sümegi et al. 2011), (15) Sárrét (Cserny \& Sümegi 2003).

C: Annual mean temperature $\left(\mathrm{T}_{\text {mean }}\right)$ and precipitation $(\mathrm{P})$ data is based on the Hungarian Meteorological Survey (OMSZ) archive from Debrecen meteorological station between 1900 and 2010. Dataset available online from: http://www.met.hu/eghajlat/magy arorszag_eghajlata/eghajlati_adatsorok/Debrecen.

D: Landcover types around Kokad mire in $10 \mathrm{~km}$ radius. The map and symbols are based on CORINE 2012 landcover data. The dotted line is the border of Hungary and Romania (European Environment Agency, 1997-1999) 

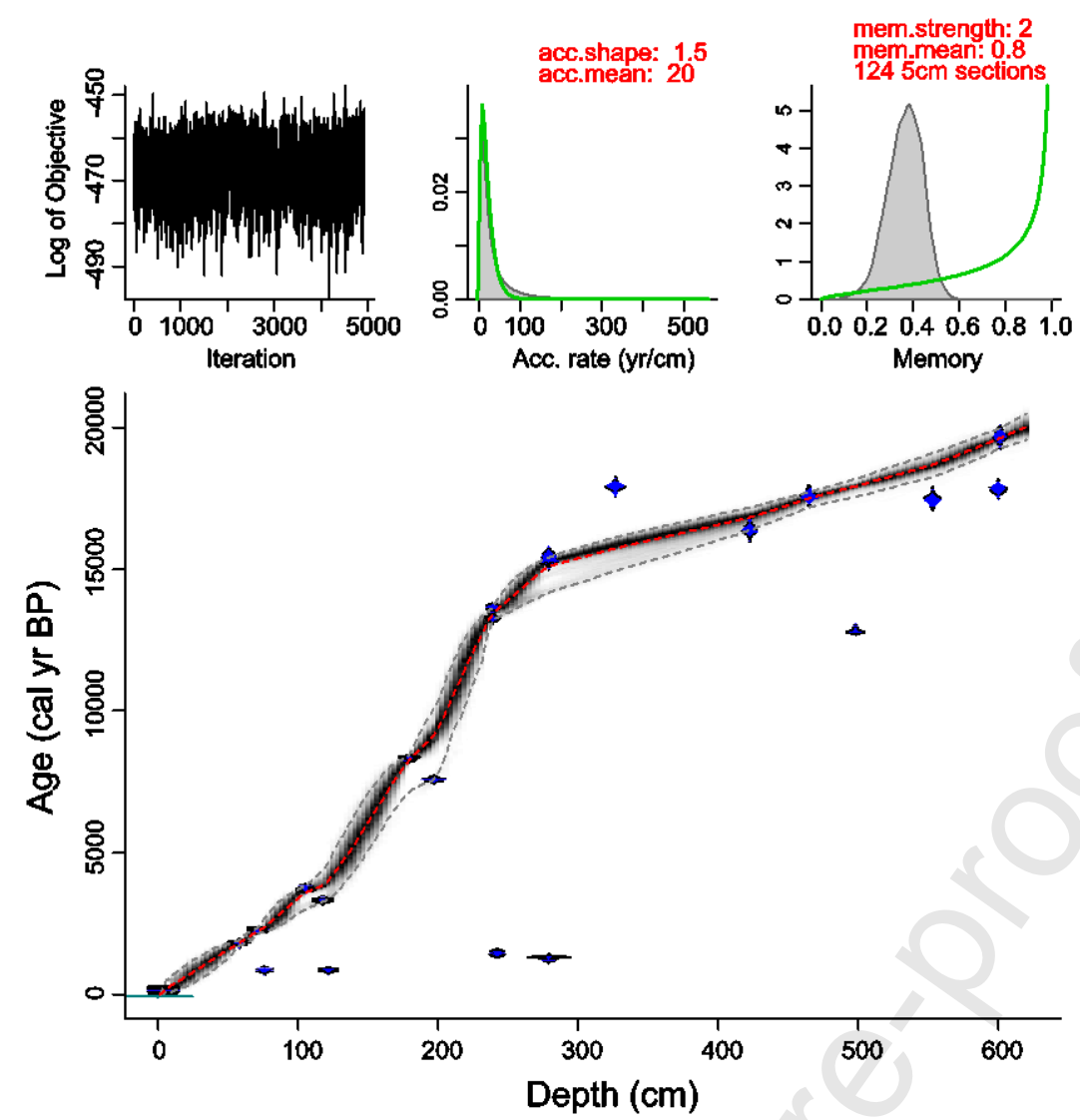

Figure 2

Depth-age model for Kokad sediment profile. The model is based on $23{ }^{14} \mathrm{C}$ dates from the sequence calibrated using CALIB Rev. 7.0.4. and the IntCal13 data-set. The age-depth model was constructed using the Bay esian method (Blaauw and Christen 2013) with the Bacon package. For the model 9 radiocarbon dates were considered as outliers. 


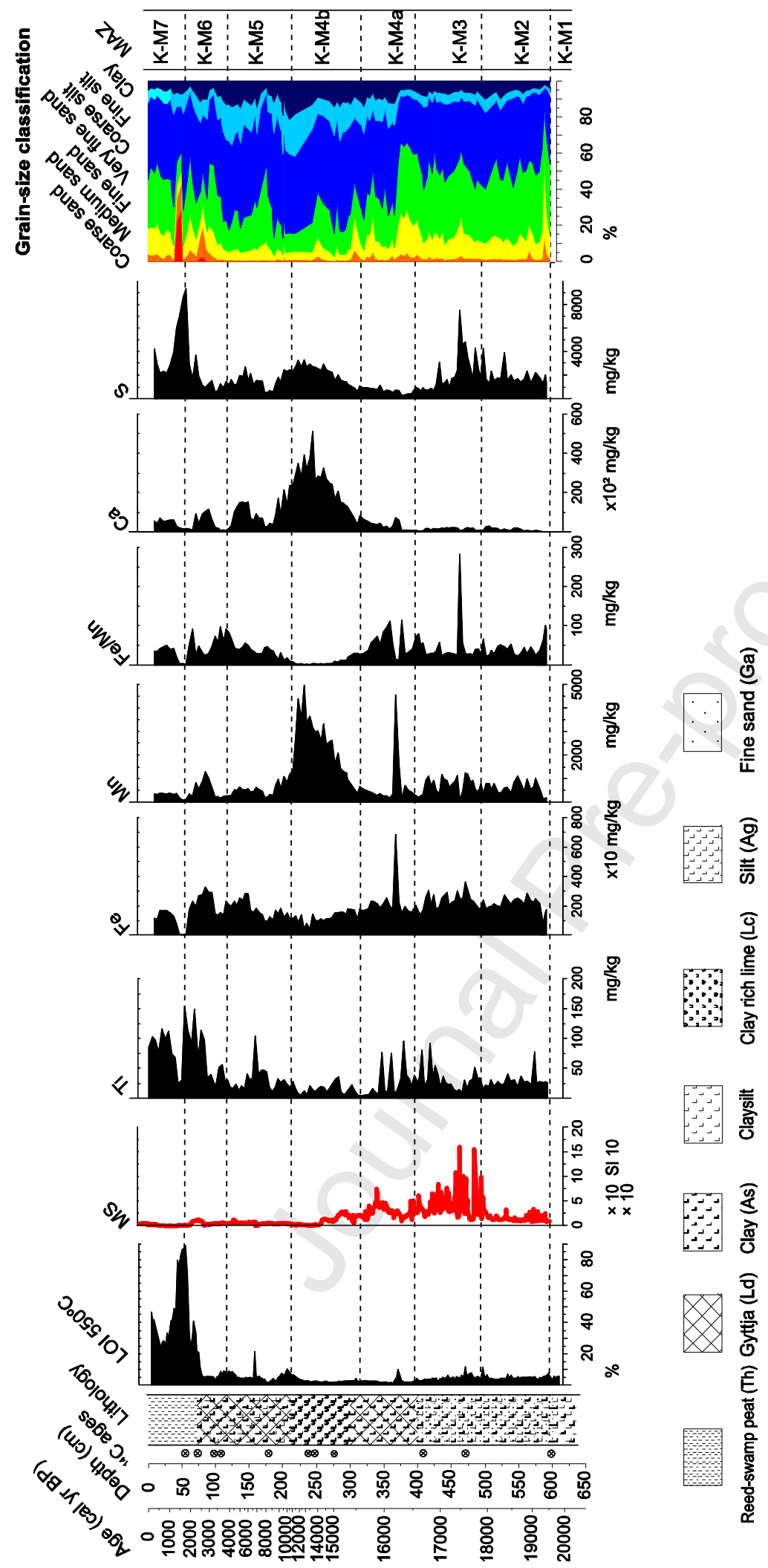

Figure 3

Sediment-composition changes in the Kokad-2 sequence as revealed by loss-on-ignition (LOI; $550^{\circ} \mathrm{C}$; \%), magnetic susceptibility (MS), selected major chemical elements (Fe, Mn, Fe/Mn, Ca, S; mg/kg) and grain-size distribution. The lithostratigraphic column (left) is represented using the symbols of Troels-Smith (1955) and detailed in Table 1. Troels-Smith symbols: Turfa herbacea (Th), Argilla steatodes (As), Detritus granosus (Dg), Limus calcareus (Lc), Limus humosus (Ld), Grana arenosa (Ga), Argilla granosa (Ag). MS measurement only covers the top $542 \mathrm{~cm}$ of the sequence. MAZ are the local macrofossil assemblage zones determined by the major changes in plant assemblages. 


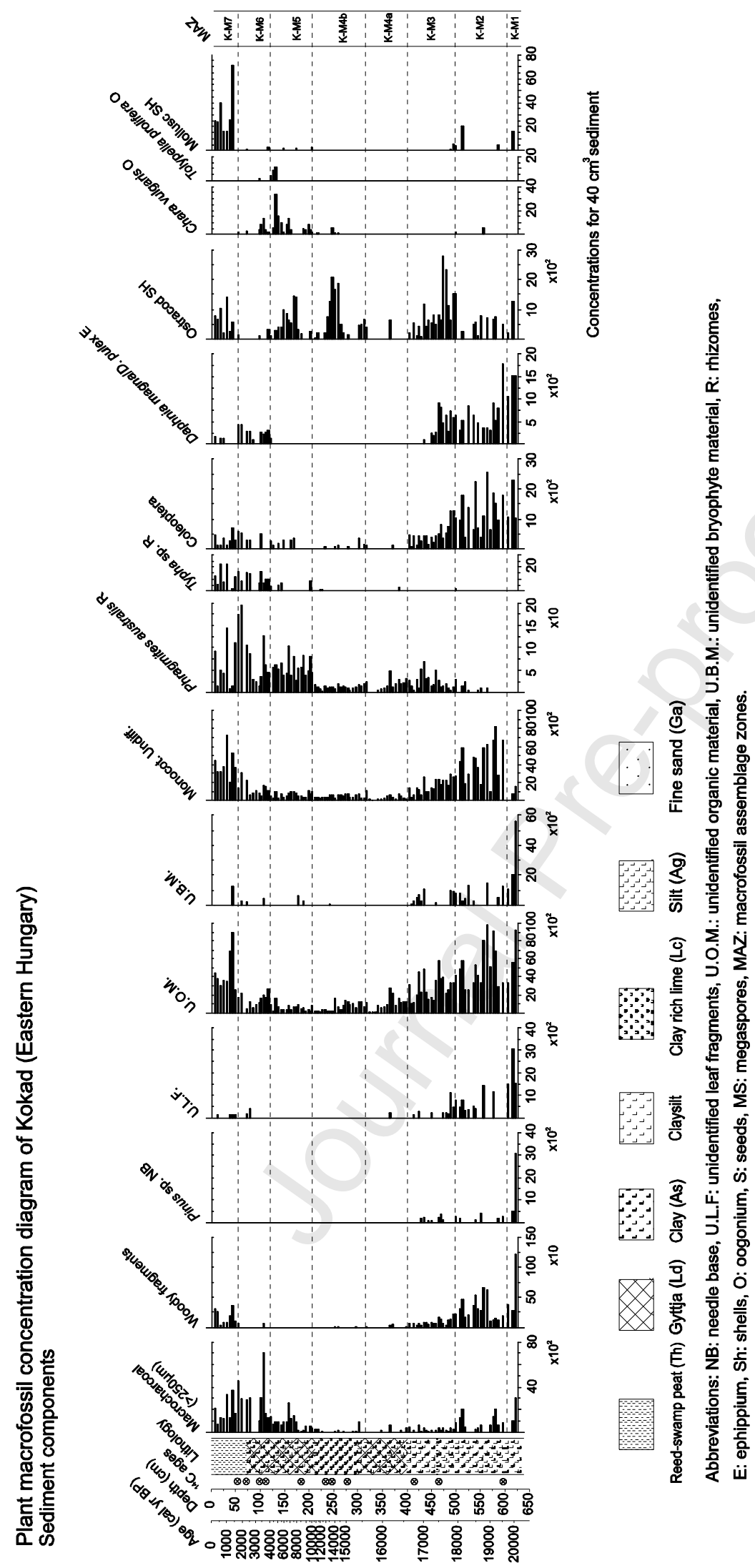

Figure 4a

Major macrofossil components of the Kokad-2 sequence. Components were counted according to a modified version of the QLCM A (semi-quantitative quadrat and leaf-count macrofossil analy sis technique) method (Jakab et al. 2004). K-M zones are local macrofossil assemblage zones in Kokad. 


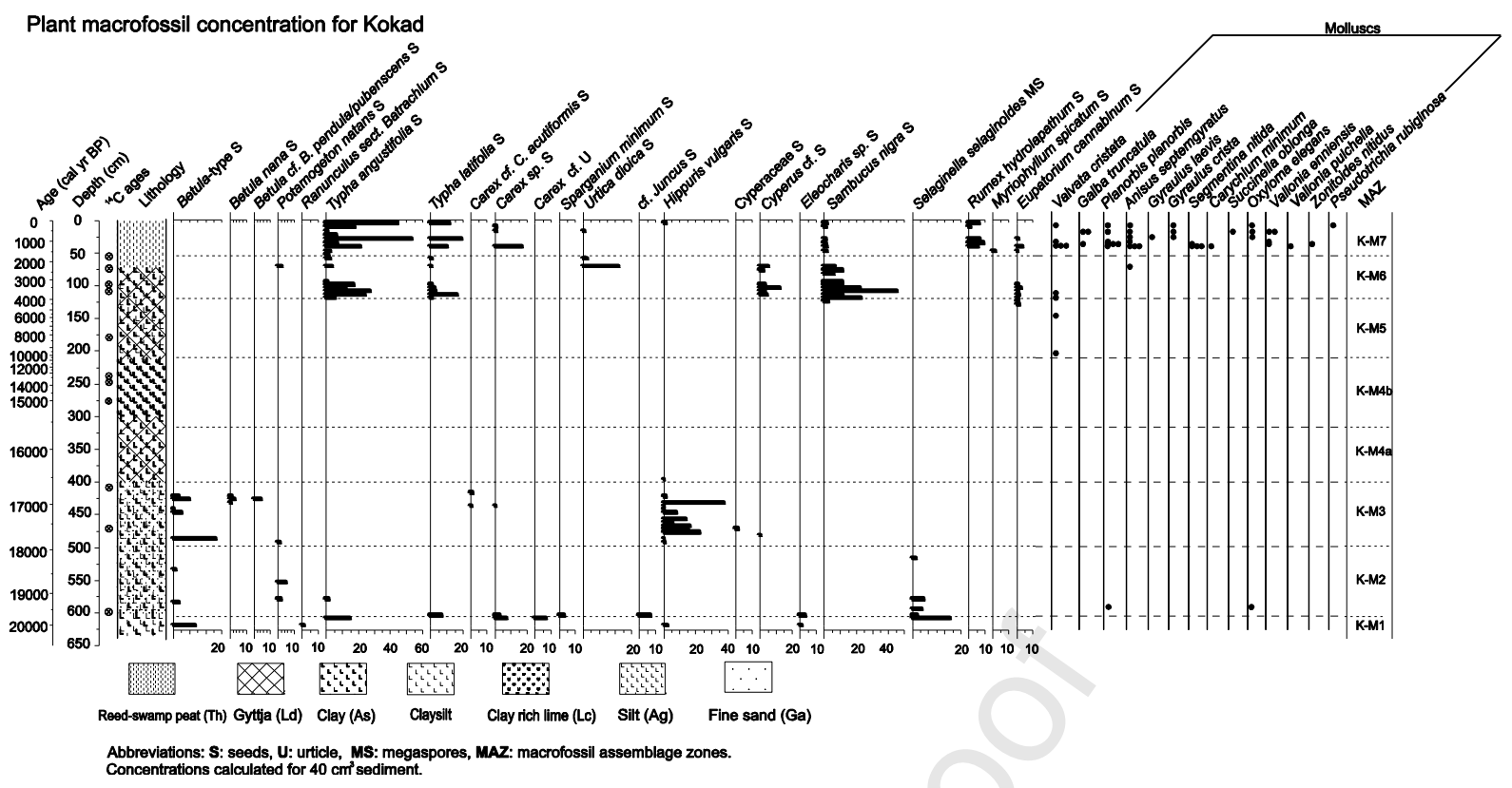

\section{Figure 4b}

Plant macrofossil concentration diagram of Kokad mire on a calibrated age scale together with the indentified mollusc shells. All macrofossil samples are standardized to $40 \mathrm{~cm}^{3}$ sediment. K-M zones are local macrofossil assemblage zones (LM AZ) in Kokad. 


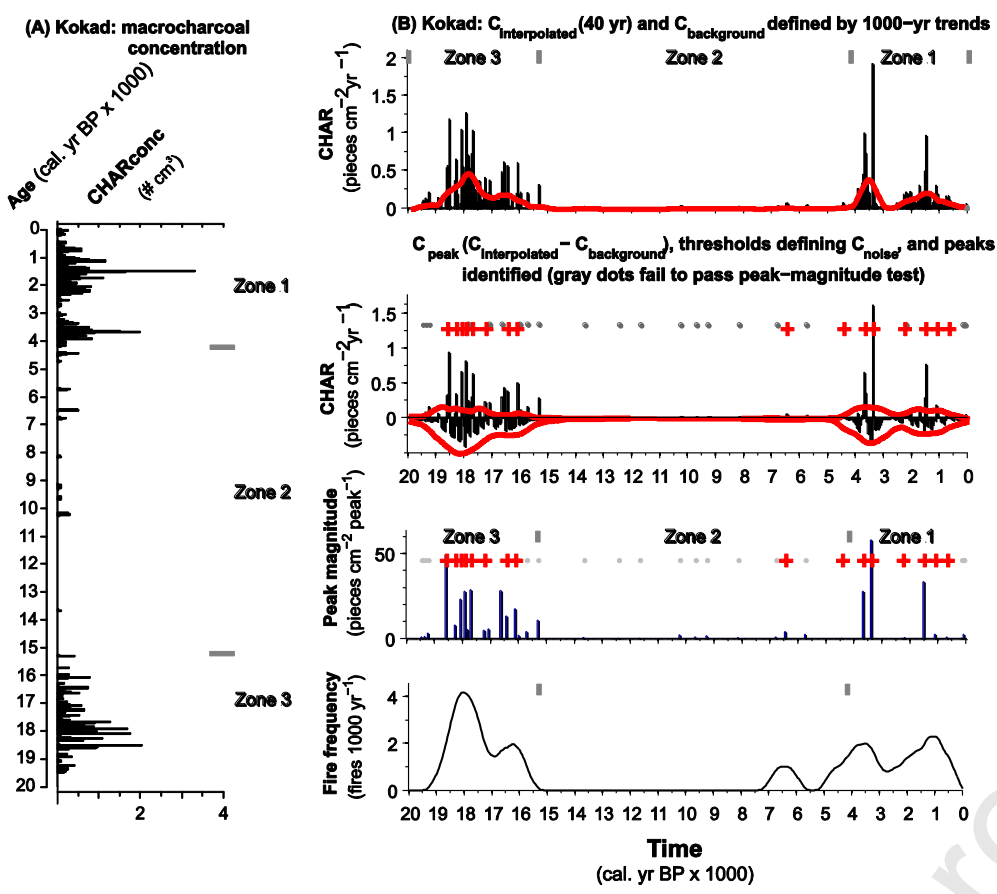

\section{Figure 5}

Macrocharcoal concentration (A) $\left(\# \mathrm{~cm}^{-3}\right)$ and accumulation rate $\left(\mathrm{CHAR}, \# \mathrm{~cm}^{-2} \mathrm{yr}^{-1}\right)$ of Kokad sequence interpolated for 40yrs $\left(\mathrm{C}_{\text {interpolated }}\right)$ and $\mathrm{C}_{\text {background }}$ defined by 1000 -yr trends $(\mathrm{B}), \mathrm{C}_{\text {peaks }}$ and threshold values defining $\mathrm{C}_{\text {noise }}$ and peaks identified (grey dots fail to pass peak-magnitude test), peak magnitude $\left(\# \mathrm{~cm}^{-2}\right.$ peak $^{-1}$ ) and fire frequency (fires $\left.1000 \mathrm{yr}^{-1}\right)$. 


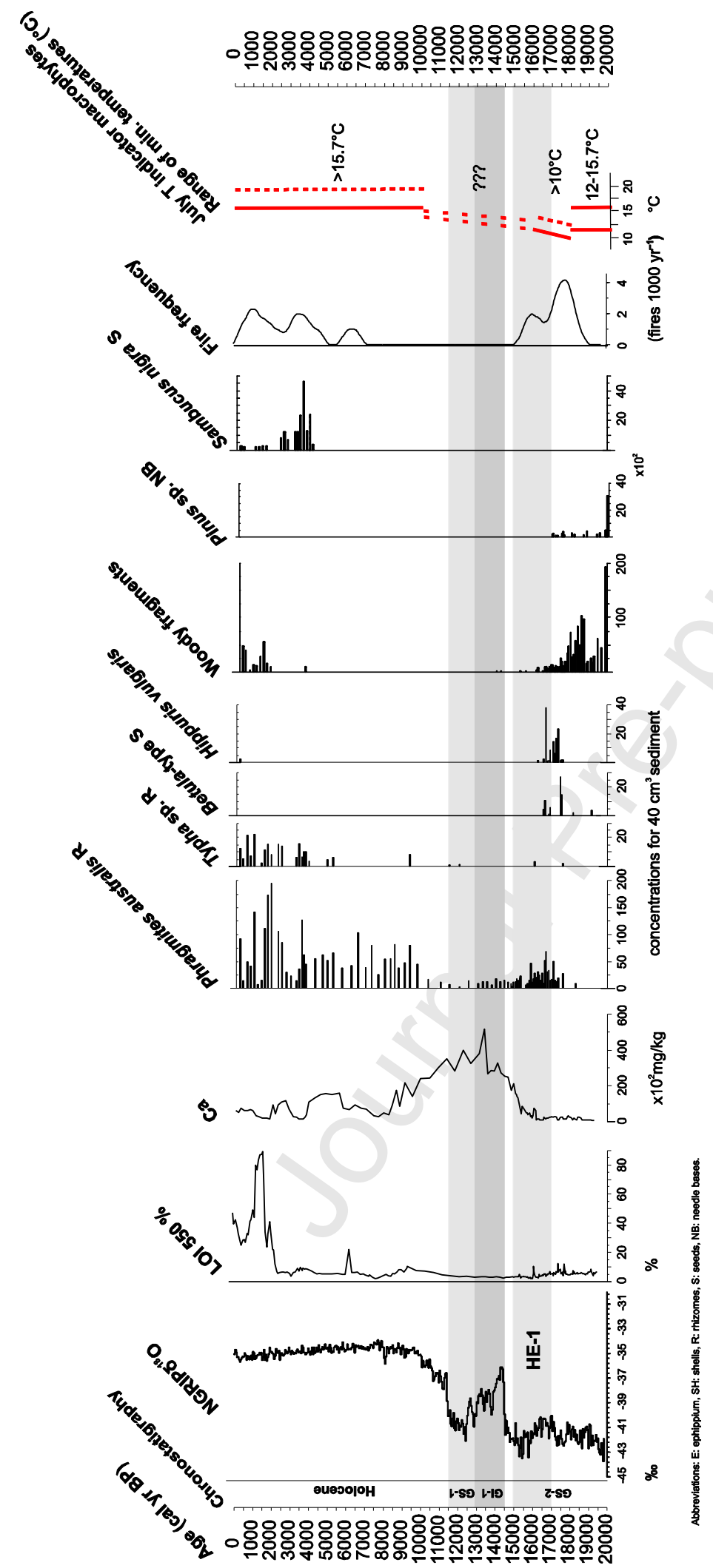

\section{Figure 6}

Summary diagram of loss-on-ignition (LOI, $\left.550^{\circ} \mathrm{C}, \%\right)$, carbonate content $(\mathrm{Ca}, \%)$ and selected plant macrofossils together with macrocharcoal-based fire frequency plotted against climatic events recorded in Greenland ice core (NGRIP; $\delta^{18} \mathrm{O}$; permill) (Rasmussen et al., 2014). Reconstructed mean minimum July temperature is based on ecological requirements of 
taxa in the plant macrofossil concentration diagram. Between 16,000 and 10,000 cal yr BP, little information is available due to the scarcity of plant remains in the sediment. 


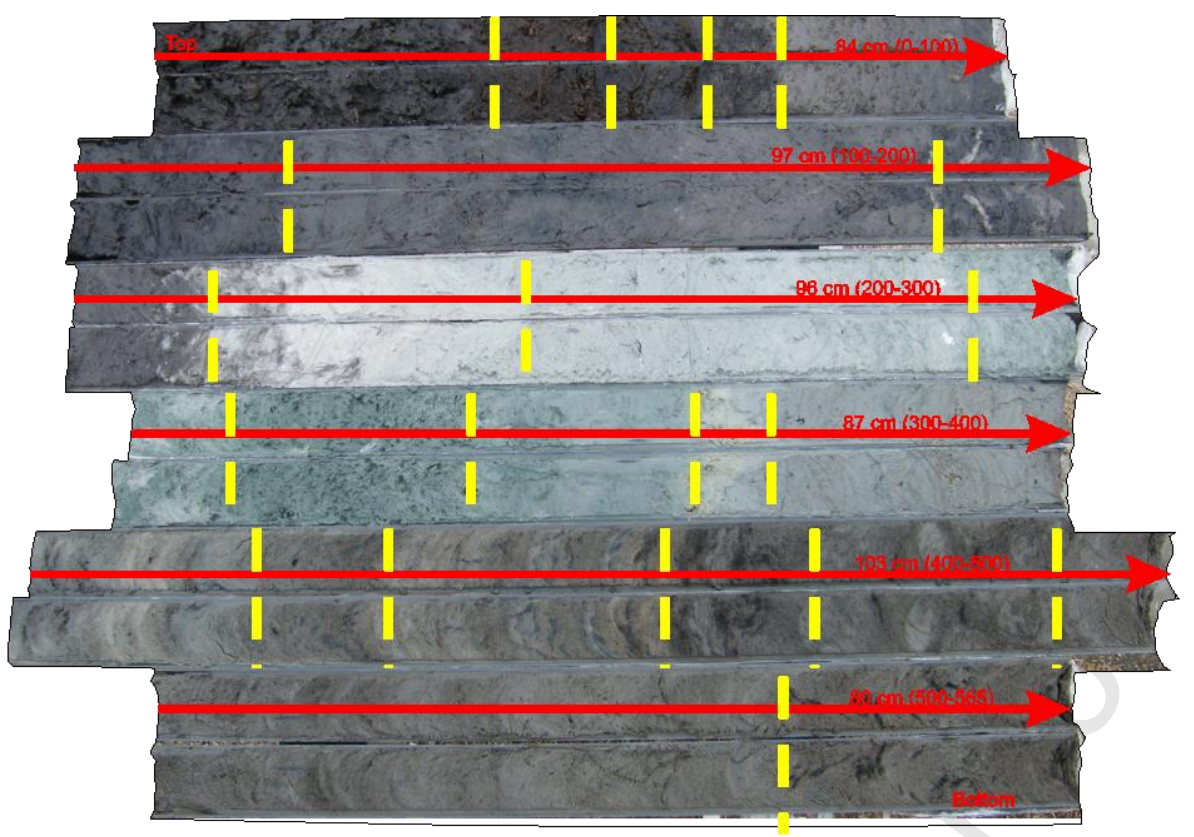

\section{Appendix A}

Sediment photograph of Kokad-2 core taken in 2008 with a Livingstone piston corer. The lowermost part $(635-600 \mathrm{~cm}$ and $600-595 \mathrm{~cm}$ ) were deposited directly after the last glacial maximum (LGM), in the Late Pleniglacial period ( GS-2.1; Rasmussen et al., 2014). The sediment is grey clay ey silt with frequent black, seemingly burnt layers. This is followed by a darker, brownish coloured silty clay between 595 and $400 \mathrm{~cm}$ and mid-brown clay ey sandy silt lay ers. The Lateglacial (300$213 \mathrm{~cm}$ ) part is lime rich clay with abundant mollusc shell remains, while the upper unit between 213 and $72 \mathrm{~cm}$ represents the Holocene with high organic content and rich in plant remains. The unit $(72-0 \mathrm{~cm})$ is blackish brown reed-swamp peat rich in mollusc shells. 

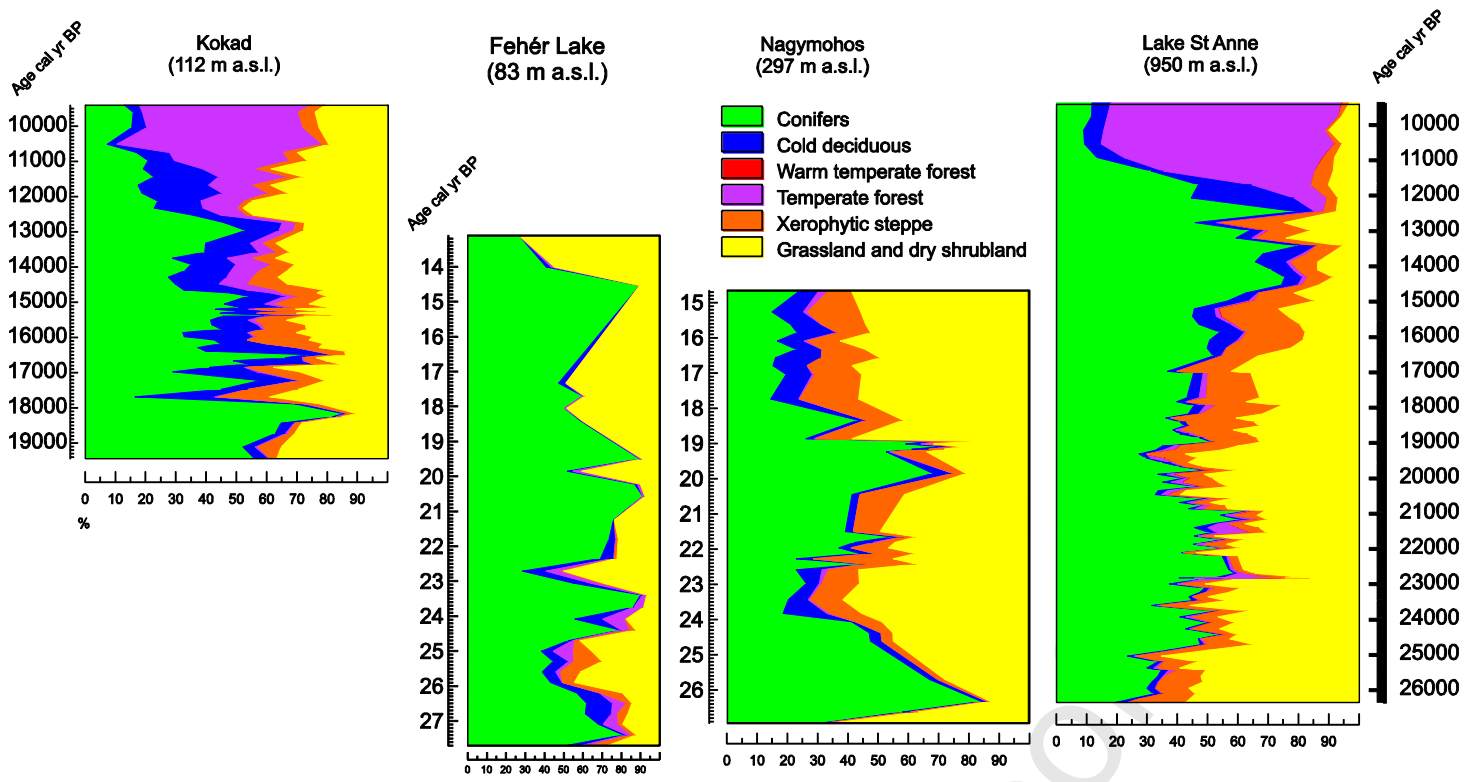

\section{Appendix B}

Summary pollen percentages diagrams for relevant site for supporting the accuracy of our age-depth model. In this region, the onset of Holocene is associated with rapid pollen percentage increase of Ulmus, Quercus and Corylus around 11,700 cal yr BP (Kokad and Lake St Anne). The rapid decrease in Cyperaceae at 16,200 cal yr BP at Kokad indicate a shift from tundra to cool coniferous forest (Magyari et al., 2019 under revision), while a massive conifer afforestation was detected around Lake St Anne at the same time (Magy ari et al., 2019 under revision). 


\section{Kokad}

\section{Grain size distribution}

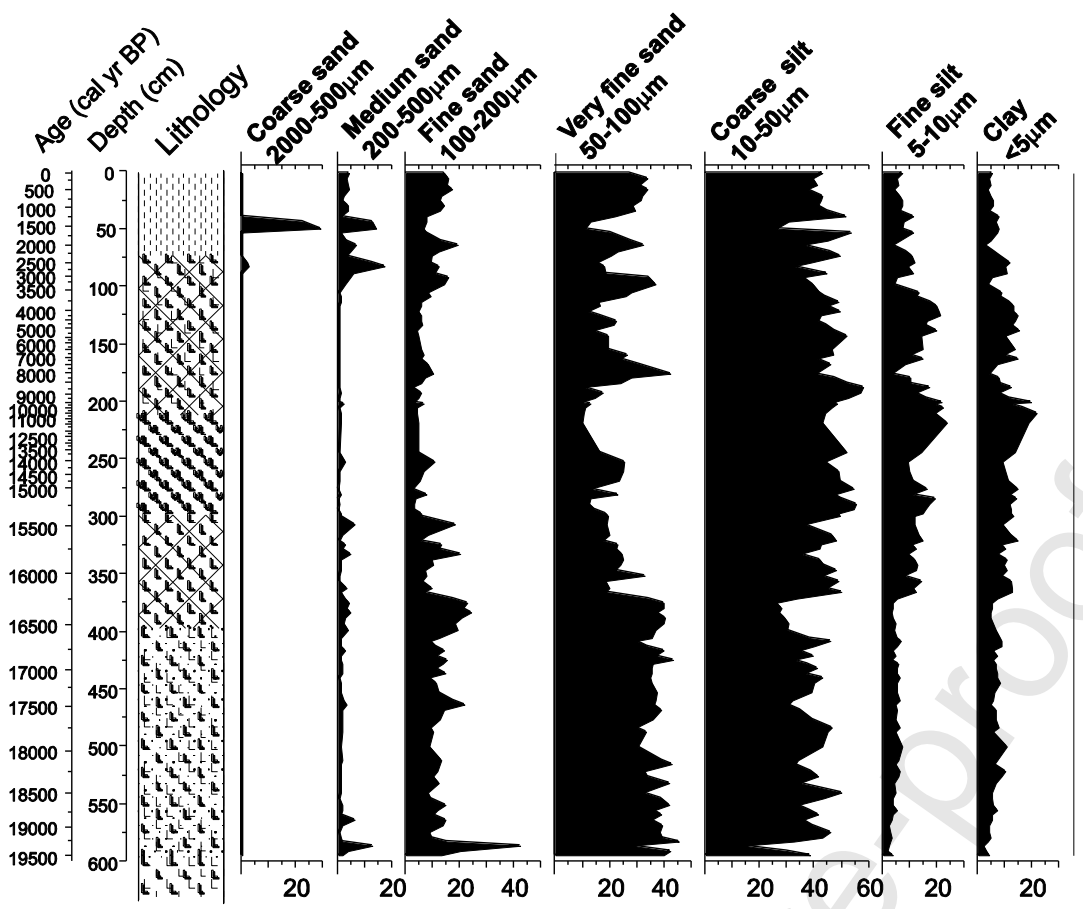

$\mathrm{V} \%$

\section{Appendix C}

Detailed grain-size distribution of Kokad sequence. The grain-size distributions were combined from the datasets using Blott $\&$ Pye (2012). 


\section{Highlights}

Palaeoclimate reconstruction and mire development in the Eastern Great Hungarian Plain for the last 20,000 years

Ildikó Vincze*, Walter Finsinger, Gusztáv Jakab, Mihály Braun, Katalin Hubay, Daniel Veres, Tamás Deli, Zoltán Szalai, Zoltán Szabó, Enikő Magyari

- Kokad was situated in the periglacial zone with continental climate during the LPG.

- This climate was characterised by relatively warm summers even during maximum cooling.

- Local vegetation change was connected to Heinrich-1 event around 17,900 cal yr BP.

- Biogenic carbonate formation imply to significant warming earlier than the Lateglacial.

- During the Holocene, strong eutrophication and drier conditions were documented. 